\title{
New particle formation in the Svalbard region 2006-2015
}

\author{
Jost Heintzenberg ${ }^{1}$, Peter Tunved ${ }^{2}$, Martí Galî ${ }^{3}$, and Caroline Leck ${ }^{4}$ \\ ${ }^{1}$ Leibniz Institute for Tropospheric Research (TROPOS), Permoserstr. 15, 04318 Leipzig, Germany \\ ${ }^{2}$ Department of Environmental Science and Analytical Chemistry (ACES), Stockholm University, \\ 10691 Stockholm, Sweden \\ ${ }^{3}$ Takuvik Joint International Laboratory \& Québec-Océan, Université Laval, G1V 0A6 Québec, Canada \\ ${ }^{4}$ Department of Meteorology, Stockholm University (MISU), 10691 Stockholm, Sweden
}

Correspondence to: Jost Heintzenberg (jost@tropos.de)

Received: 30 November 2016 - Discussion started: 1 December 2016

Revised: 13 April 2017 - Accepted: 18 April 2017 - Published: 19 May 2017

\begin{abstract}
Events of new particle formation (NPF) were analyzed in a 10-year data set of hourly particle size distributions recorded on Mt. Zeppelin, Spitsbergen, Svalbard. Three different types of NPF events were identified through objective search algorithms. The first and simplest algorithm utilizes short-term increases in particle concentrations below $25 \mathrm{~nm}$ (PCT (percentiles) events). The second one builds on the growth of the sub-50 nm diameter median (DGR (diameter growth) events) and is most closely related to the classical "banana type" of event. The third and most complex, multiple-size approach to identifying NPF events builds on a hypothesis suggesting the concurrent production of polymer gel particles at several sizes below ca. $60 \mathrm{~nm}$ (MEV (multisize growth) events).

As a first and general conclusion, we can state that NPF events are a summer phenomenon and not related to Arctic haze, which is a late winter to early spring feature. The occurrence of NPF events appears to be somewhat sensitive to the available data on precipitation. The seasonal distribution of solar flux suggests some photochemical control that may affect marine biological processes generating particle precursors and/or atmospheric photochemical processes that generate condensable vapors from precursor gases. Notably, the seasonal distribution of the biogenic methanesulfonate (MSA) follows that of the solar flux although it peaks before the maxima in NPF occurrence.

A host of ancillary data and findings point to varying and rather complex marine biological source processes. The potential source regions for all types of new particle formation appear to be restricted to the marginal-ice and open-water areas between northeastern Greenland and eastern Svalbard.
\end{abstract}

Depending on conditions, yet to be clarified new particle formation may become visible as short bursts of particles around $20 \mathrm{~nm}$ (PCT events), longer events involving condensation growth (DGR events), or extended events with elevated concentrations of particles at several sizes below $100 \mathrm{~nm}$ (MEV events). The seasonal distribution of NPF events peaks later than that of MSA and DGR, and in particular than that of MEV events, which reach into late summer and early fall with open, warm, and biologically active waters around Svalbard. Consequently, a simple model to describe the seasonal distribution of the total number of NPF events can be based on solar flux and sea surface temperature, representing environmental conditions for marine biological activity and condensation sink, controlling the balance between new particle nucleation and their condensational growth. Based on the sparse knowledge about the seasonal cycle of gel-forming marine microorganisms and their controlling factors, we hypothesize that the seasonal distribution of DGR and, more so, MEV events reflect the seasonal cycle of the gel-forming phytoplankton.

\section{Introduction}

In the late 1970s and early 1980s, the interest in the Arctic atmospheric aerosol widened from the well-identified winter phenomenon of Arctic haze (Rahn and Shaw, 1977; Heintzenberg and Leck, 1994) to summer conditions in this northernmost remote region. In the pristine Arctic summer air the background aerosol (Junge, 1963) was expected to be most clearly visible, far away from the Northern Hemi- 
sphere anthropogenic emission centers at lower latitudes. Episodic and localized occurrences of high concentrations of ultrafine particles (here defined as particles with diameters $<100 \mathrm{~nm}$ ) in the summer Arctic were explained by the rare import of polluted air from lower latitudes (Flyger and Heidam, 1978; Heintzenberg and Larssen, 1983) or hypothetical anthropogenic sources in the Arctic (Jaenicke and Schütz, 1982).

With the advent of sensitive condensation nuclei counters (Agarwal and Sem, 1980) and differential mobility analyzers (Knutson and Whitby, 1975a, b) more details became visible in the Arctic sub-micrometer aerosol. High numbers of ultrafine particles were observed in connection with fog passages (Lannefors et al., 1983) and chemical aerosol information indicated regional - possibly biogenic - particle sources in the summer Arctic (Heintzenberg, 1989). The high molar ratios of methane sulfonate (MSA) to non-sea salt sulfate $\left(\mathrm{nsSO}_{4}^{2-}\right.$ ) of 0.28 in the Arctic summer aerosol found by Heintzenberg and Leck (1994) substantiated the biogenic source of the particles.

The establishment of long-term Arctic aerosol monitoring at the fringes of the pack ice in Alaska (e.g., Polissar et al., 1999), Canada (e.g., Norman et al., 1999; Willis et al., 2016), and on Spitsbergen (e.g., Tunved et al., 2013) revealed more details of potential sources of the summer aerosol, in particular their connection to the marine biosphere in the Arctic. The unique series of systematic aerosol studies in the central Arctic north of $80^{\circ} \mathrm{N}$ onboard the Swedish icebreaker Oden in 1996 led to the formulation of a new hypothesis concerning a specific process of marine biogenic particle formation (Leck and Bigg, 1999). The marine biogenic particles involved behaved as polymer gels and originated in the surface microlayer (SML) of the ocean (Orellana et al., 2011b) from the activity of sea ice algae, phytoplankton, and perhaps bacteria. The new particle events were reported to occur as simultaneous enhancement of particle number concentrations in the whole size range below $50 \mathrm{~nm}$, and not with the prototypical "banana growth" (Kulmala et al., 2004). Two more Oden cruises in 2001 and 2008 yielded results that were partly contradicting (Held et al., 2011a, b), partly supporting the SML hypothesis (Leck et al., 2013; Karl et al., 2013; Orellana et al., 2011b; Leck and Bigg, 2010). The synopsis of the results of four Oden cruises of Heintzenberg et al. (2015) identified geographic regions of new particle formation (NPF) in the inner Arctic while stressing the importance of recent openwater and related biological activity in the sea in transects by air masses with new particle formation over the central Arctic.

In total, 2 years of aerosol size distributions from Mt. Zeppelin, Spitsbergen, and Alert, Nunavut both located at the fringes of the central pack ice, were analyzed by Croft et al. (2016a) with a global aerosol geophysics model. They discuss classical new-particle nucleation, coagulation scavenging in clouds, scavenging by precipitation, and transport in order to explain the annual cycle of the Arctic aerosol. Croft et al. (2016a) found two seasonal maxima in their modeled particle nucleation rates, one in March, and one in July. In spring, their simulated NPF occurs mainly in the free troposphere, whereas in summer, it also occurs in the planetary boundary layer. More recently, Croft et al. (2016b) stated that ammonia from seabird-colony guano is a key factor contributing to bursts of newly formed particles, which are observed every summer in the near-surface atmosphere, at least at Alert, Nunavut, Canada. Earlier, the results of studies with another global aerosol model by Browse et al. (2014) suggested that the potential increase in NPF in the Arctic with potential increases in cloud condensation nuclei is compensated by wet scavenging. They also state that scavenging by pre-existing large particles suppresses NPF events.

Based on 3 years of data from the two Arctic sites Thule and Ny-Ålesund (gruvebadet), Becagli et al. (2016) examined the sources and environmental factors controlling the biological aerosol component MSA. Their analysis included satellite-derived Chlorophyll $a$ (an indicator of phytoplankton biomass), oceanic phytoplankton primary productivity (PPP), and sea ice. Whereas they found good correlations between MSA, PPP, and sea ice (the latter two being closely related), their data did not allow for any statements on NPF processes.

To date the longest record of sub-micrometer numbersize distributions of the Arctic aerosol down to $5 \mathrm{~nm}$ particle diameter and below has been accumulated on Mt. Zeppelin, Spitsbergen (Tunved et al., 2013; Heintzenberg and Leck, 1994). For the 10 years from 2006 through 2015 a total of 63936 quality-controlled hours of aerosol data are available, i.e., during $73 \%$ of all hours of the 10 years. In the present study we exploit this formidable data set in a search for processes forming new particles. An important first step in this work was formulating completely objective criteria for the identification of events. In the relatively clean Arctic environment, we do not expect the classical nucleation and growth events as frequently observed over the continents (cf. Kulmala et al., 2004) to dominate. Thus, we refrained from applying the objective search algorithm formulated by Heintzenberg et al. (2007) for this banana type of events. Instead we formulated new objective search algorithms allowing for several potential types of new particle formation events or formation processes. With a host of complementary atmospheric and surface physical, chemical, and biological information, a large number of NPF events identified with these algorithms will be analyzed in the following chapters.

\section{Database}

\section{The Mt. Zeppelin observatory}

Situated at the top of Mt. Zeppelin, Svalbard $\left(78^{\circ} 56^{\prime} \mathrm{N}\right.$, $11^{\circ} 53^{\prime} \mathrm{E}$ ), the Zeppelin observatory offers a unique possibility to study the characteristic features of Arctic atmo- 
spheric constituents such as trace gases and aerosol particles. At a height of $474 \mathrm{~m}$ a.s.l., the station is located near the top of the local planetary boundary layer and represents remote Arctic conditions. The closest source of pollution, the small community of Ny-Ålesund, is located $\sim 2 \mathrm{~km}$ north of the station (http://www.esrl.noaa.gov/psd/iasoa/sites/default/ files/stations/nyalesund/nyalesund_site.jpg). However, the elevation difference and typical wind patterns largely prevent pollution from nearby sources to reach the Zeppelin observatory. The dominating wind pattern is east-southeast katabatic flow from Kongsvegen glacier or from northwesterly directions as channeled by the Kongsfjord (Beine et al., 2001; Heintzenberg et al., 1983). The station itself was initially established in 1991, and is owned by the Norwegian Polar Research Institute (NP). The Norwegian Institute for Air Research (NILU) is responsible for the coordination of the scientific program.

\subsection{Physical aerosol data}

After a period of continuous aerosol measurements by the Department of Meteorology, Stockholm University, in the early 1990s (Heintzenberg and Leck, 1994), the Department of Analytical Chemistry and Environmental Science, Stockholm University, initialized observations of the aerosol number-size distribution in mid-2000. Originally, the system consisted of a single differential mobility analyzer system (DMPS) consisting of a medium-size Hauke-type differential mobility analyzer (DMA) together with a TSI 3760 condensation particle counter, covering diameters between 20 and $\sim 500 \mathrm{~nm}$. Since 2006 the particle size range has been widened covering particle sizes between 10 and $790 \mathrm{~nm}$. In 2005, the rain cover over the inlet was replaced. Initially, the instrument inlet was of a $\mathrm{PM}_{10}$ type, removing particles or hydrometeors with diameters $>10 \mu \mathrm{m}$ from the sampled air stream. During a substantial renewal of the Stockholm University equipment in 2010-2011, both inlet and DMPS systems were replaced.

Since then, the DMPS system has utilized a custom-built twin DMA setup comprising one Vienna-type medium DMA (Reischl, 1991) coupled to a TSI CPC 3010 covering sizes between 25 and $800 \mathrm{~nm}$ and a Vienna-type long DMA coupled with at TSI CPC 3772 covering sizes between 5 and $60 \mathrm{~nm}$. The size distributions from the two systems are harmonized on a common size grid and then merged. Both systems use a closed-loop flow setup. The current inlet hat is of whole air type, complying with EUSAAR ${ }^{1}$ standard for high-altitude or Arctic sampling conditions. In the current setup, the inlet is operated with a flow of ca. $100 \mathrm{~L} \mathrm{~min}^{-1}$

\footnotetext{
${ }^{1}$ EUSAAR (European Supersites for Atmospheric Aerosol Research) is an EU-funded I3 (Integrated Infrastructures Initiatives) project carried out in the FP6 framework of the specific research and technological development gram "Structuring the European Research Area - Support for Research Infrastructures" (http://www. eusaar.net/files/data/data_protocol.cfm).
}

(lpm). Laminar flow conditions apply throughout the sampling lines. Outside of the station, the inlet temperature is kept above $0{ }^{\circ} \mathrm{C}$ using active heating. Inside the station the temperature increases gradually to room temperature (maximum temperature reaches ca. $25^{\circ} \mathrm{C}$, but remains typically around $20^{\circ} \mathrm{C}$ ). Relative humidity (RH) and temperature are internally monitored and measurements are maintained at dry conditions with $\mathrm{RH}<30 \%$. The system is regularly checked with latex spheres and flow controls. The recorded data are manually screened and cross-checked with other available observation as in Tunved et al. (2013). If inconsistencies were found between the different data sets, further investigation was performed to exclude data that were identified as affected by instrumental errors. Using the instrumental logbook, periods of local activity potentially influencing the sampling were also excluded from the data set. During the years 2006-2010 no particles below $10 \mathrm{~nm}$ in diameter were recorded. Since 2011 four more diameter bins down to $5 \mathrm{~nm}$ have been included and a different diameter array was utilized. To allow for a synopsis of all years, all size distributions were interpolated on the pre-2011 diameter array and all integrals of the size distribution over particle diameter were taken over the joint diameter range 10 to $631 \mathrm{~nm}$. For the pre-2011 years the data at the four size channels below $10 \mathrm{~nm}$ were flagged as missing. However, whenever results cover the complete time series the resulting number concentrations in the four first channels covering the years 20112015 are carried along.

For the identification of NPF in terms of particle growth, the parameter D50 in nanometer was calculated as the number median diameter of particles smaller than $50 \mathrm{~nm}$ but larger than $10 \mathrm{~nm}$, i.e., $50 \%$ of all particles below that size are smaller than D50. Besides this parameter Table 1 lists nine integral particle parameters, which are utilized in the NPF-search approaches or in the interpretation of results. These aerosol parameters quantify total particle number (NTO) and particle numbers in sub-ranges of the numbersize distribution such as $N 25$, quantifying the total number of particles between 10 and $25 \mathrm{~nm}$.

Following the concept developed by Pirjola et al. (1999) and Kulmala et al. (2001), we calculated the condensation sink $\left(\mathrm{CS}, \mathrm{s}^{-1}\right)$ as a parameter with which the probability of new particle formation from the gas phase and the necessary amount of condensable vapor can be estimated. We utilized number-size distributions, pressure, and temperature taken from our database for this calculation.

\subsection{Chemical aerosol data}

For the interpretation of NPF events we employed chemical information derived from the analyses of high-volume particle samples taken by the Norwegian Institute for Air research (NILU). A high-volume sampler $\left(\mathrm{PM}_{10}\right)$ was used to collect samples for a quantitative determination of sodium $\left(\mathrm{Na}^{+}\right)$, sulfate $\left(\mathrm{SO}_{4}^{2-}\right)$, and MSA $\left(\mathrm{CH}_{3} \mathrm{SOO}^{-}\right)$. The sam- 
Table 1. Aerosol, atmospheric, and ocean parameters utilized in the present study. DMSPt is total dimethylsulfoniopropionate in surface ocean waters. TR is temporal resolution in which the respective data were available. All parameter explanations starting with "Trajectory" refer to parameters calculated by HYSPLIT4 at each trajectory step.

\begin{tabular}{|c|c|c|}
\hline Parameter & $\mathrm{TR}(\mathrm{h})$ & Explanation \\
\hline$C 25$ & $1 \mathrm{~min}$ & $25 \%$ percentile of cloud base from AWI ceilometer $(\mathrm{m})$ \\
\hline $\mathrm{CF} 12,24,36,48,5 \mathrm{D}$ & 24 & $\begin{array}{l}\text { Average MODIS cloud fraction during the last } 12 \mathrm{~h}, 24 \mathrm{~h}, 36,48 \mathrm{~h} \text {, and days } 3-5 \\
\text { before trajectory arrival }\end{array}$ \\
\hline D50 & 1 & Number median diameter of particles $<50 \mathrm{~nm}$ diameter \\
\hline $\mathrm{CS}$ & 1 & Condensation sink $\left(\mathrm{s}^{-1}\right)$ \\
\hline $\mathrm{DZ}$ & 1 & Vertical trajectory displacement $\left(\mathrm{m} \mathrm{h}^{-1}\right)$ during the last hour before arrival \\
\hline MSA & $\geq 1$ day & Methane sulfonate $\left(\mathrm{nmol} \mathrm{m}^{-3}\right)$ \\
\hline$N 10$ & 1 & Number concentration of particles up to $10 \mathrm{~nm}\left(>2010, \mathrm{~cm}^{-3}\right)$ \\
\hline$N 20$ & 1 & Number concentration between 10 and $20 \mathrm{~nm}\left(\mathrm{~cm}^{-3}\right)$ \\
\hline$N 25$ & 1 & Number concentration of particles up to $25 \mathrm{~nm}\left(\mathrm{~cm}^{-3}\right)$ \\
\hline$N 40$ & 1 & Number concentration between 20 and $40 \mathrm{~nm}\left(\mathrm{~cm}^{-3}\right)$ \\
\hline N60 & 1 & Number concentration between 40 and $60 \mathrm{~nm}\left(\mathrm{~cm}^{-3}\right)$ \\
\hline$N 100$ & 1 & Number concentration between 60 and $100 \mathrm{~nm}\left(\mathrm{~cm}^{-3}\right)$ \\
\hline N300 & 1 & Number concentration between 100 and $300 \mathrm{~nm}\left(\mathrm{~cm}^{-3}\right)$ \\
\hline $\mathrm{Na}$ & $\geq 1$ day & Sodium concentrations $\left(\mathrm{nmol} \mathrm{m}^{-3}\right)$ \\
\hline $\mathrm{NCO}$ & 1 & Number concentration of particles $>300 \mathrm{~nm}\left(\mathrm{~cm}^{-3}\right)$ \\
\hline $\mathrm{nssSO}_{4}^{2-}$ & $\geq 1$ day & Non-sea salt sulfate concentrations $\left(\mathrm{nmol} \mathrm{m}^{-3}\right)$ \\
\hline NTO & 1 & Number concentration of particles $\geq 10 \mathrm{~nm}, \mathrm{~cm}^{-3}$ ) \\
\hline $\mathrm{OC} 12,24,36,48,5 \mathrm{D}$ & 120 & $\begin{array}{l}\text { Average MODIS DMSPt (nmol) during the last } 12 \mathrm{~h}, 24 \mathrm{~h}, 36,48 \mathrm{~h} \text {, and days } 3- \\
5 \text { before trajectory arrival }\end{array}$ \\
\hline OW12, 24, 36, 48, 5D & 24 & $\begin{array}{l}\text { Average open water (\%) during the last } 12 \mathrm{~h}, 24 \mathrm{~h}, 36,48 \mathrm{~h} \text {, and days } 3-5 \text { before } \\
\text { trajectory arrival }\end{array}$ \\
\hline PRE & 1 & Trajectory precipitation $(\mathrm{mm})$ at arrival \\
\hline RH & 1 & Trajectory relative humidity $(\%)$ at arrival \\
\hline SFL & 1 & Solar flux at trajectory arrival $\left(\mathrm{Wm}^{-2}\right)$ \\
\hline $\mathrm{SP} 12,24,36,48,5 \mathrm{D}$ & 1 & $\begin{array}{l}\text { Accumulated precipitation }(\mathrm{mm}) \text { during the last } 12 \mathrm{~h}, 24 \mathrm{~h}, 36,48 \mathrm{~h} \text {, and days } 3- \\
5 \text { before trajectory arrival }\end{array}$ \\
\hline$T 12,24,36,48,5 \mathrm{D}$ & 24 & $\begin{array}{l}\text { Average sea surface temperature (C) during the last } 12 \mathrm{~h}, 24 \mathrm{~h}, 36,48 \mathrm{~h} \text {, and } \\
\text { days 3-5 before trajectory arrival }\end{array}$ \\
\hline TEM & 1 & Trajectory temperature (C) at arrival \\
\hline WDR & 1 & Trajectory wind direction $\left(^{\circ}\right)$ during the last hour before arrival \\
\hline WSP & 1 & Trajectory wind speed $\left(\mathrm{m} \mathrm{s}^{-1}\right)$ during the last hour before arrival \\
\hline
\end{tabular}

pler collected material for analysis in 1 to 3 days. Blank samples were obtained by mounting the glass fiber filters at the sampling site with the same sampling period but without air passing through. $\mathrm{Na}^{+}$and $\mathrm{SO}_{4}^{2}$ were analyzed by NILU and have been downloaded for the present study from the EBAS database (http://ebas.nilu.no), which list details about the sampling technique and the sampling protocol; $\mathrm{nssSO}_{4}^{2-}$ was determined from total sulfate correcting for sea salt sulfate as $0.25 \mathrm{xNa}^{+}$(Keene et al., 1986).

MSA was analyzed at the laboratory of the Department of Meteorology, Stockholm University. To allow for subsequent chemical determinations the ambient samples and blanks were carefully handled in a glove box (free from particles, sulfur dioxide, and ammonia). At the time of the chemical analyses, still in the glove box, the substrates were extracted (in centrifuge tubes) with $60 \mathrm{~cm}^{3}$ deionized water (Millipore Alpha-Q, conductivity $18 \mathrm{M} \Omega \mathrm{cm}$ ). The extracts were there- after analyzed for weak anions by chemically suppressed ion chromatography (IC, Dionex ICS-2000) using Dionex AG11/AS11 columns. In order to trap carbonates and other ionic contaminants a Dionex ATC-1 column was used before the injection valve. The injection volume was $50 \mu \mathrm{d} \mathrm{m}^{3}$. Quality checks of the IC-analyses were performed with both internal and external reference samples (Das et al., 2011). The analytical detection limits obtained for the various ions, defined as twice the level of peak-to-peak instrument noise,

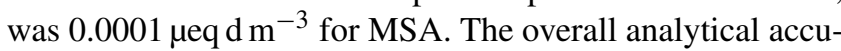
racy was better than $1.5 \%$.

\subsection{Back trajectories and meteorological data}

For every hour during the 10 years 2006 through 2015, three-dimensional back trajectories were calculated arriving at $474 \mathrm{~m}$ at Mt. Zeppelin. The trajectories were calculated 
backward for up to 10 days using the HYSPLIT4 model (Draxler and Rolph, 2003) with meteorological data from the Global Data Assimilation System with $1 \%$ resolution (GDAS1). Trajectories extending backwards for 10 days are inaccurate at origin due to the trajectory uncertainty of 25$30 \%$ of its length (Stohl, 1998). More information about the GDAS data set can be found at Air Resources Laboratory (ARL) NOAA (http://ready.arl.noaa.gov), from which the meteorological data were downloaded.

During the analyzed time period, meteorological records at the Mt. Zeppelin station were rather limited in quality and were frequently interrupted. There are no precipitation measurements and wind measurements are strongly influenced by the station building and by the local topography. In order to have an internally consistent and unbroken meteorological record we utilized hourly meteorological parameters at trajectory arrival times as calculated by the HYSPLIT4 model. We emphasize that their accuracy depends on the quality of the meteorological model inside HYSPLIT4 and the accuracy and representativeness of the meteorological fields utilized by the model. Of the local meteorological record, air temperature was considered the most reliable and thus explored in a comparison of trajectory calculated and modeled meteorological data. When comparing the 42600 contiguous hourly records from 1 January 2008 to 10 November 2012 the average ratio of measured and calculated temperatures is 0.98 , with a coefficient of determination of 0.96 . The utilized model parameters are listed in Table 1.

As an additional parameter we evaluated the vertical air movement of the trajectories during the last hour before arrival by subtracting the trajectory height $1 \mathrm{~h}$ before arrival at the arrival height of $474 \mathrm{~m}$. The resulting vertical displacement parameter (DZ) is given in meters per hour. Positive values of $\mathrm{DZ}$ indicate a lifting of the air.

The most important missing meteorological information concerns the local cloud cover. No direct recording was available of times during which the station was in clouds. The closest available cloud instrument is a ceilometer operated by the Alfred Wegener Institute (AWI) at their Koldewey Station in Ny-Ålesund, i.e., in the valley below Mt. Zeppelin, some $2.8 \mathrm{~km}$ of horizontal distance from the position of the mountain station. From the $1 \mathrm{~min}$ records of the ceilometer, we derived hourly values of the $25 \%$ percentile of cloud base, which was used as an indicator for the Zeppelin station being in clouds. This ceilometer parameter is listed as $C 25$ in Table 1.

Precipitating clouds scavenge the planetary boundary layer and thus reduce the available particle surface as condensation sink of particle precursors. As a consequence nucleation from the gas phase may be facilitated (Tunved et al., 2013). As in Tunved et al. (2013), we utilized the HYSPLITmodeled precipitation along the back trajectories. Sums of precipitation (SP; see Table 1) were calculated along each back trajectory and will be referred to as SP1 (during the last day), SP2 (during the last but 1 day), and SP5 (during days 3 to 5) before arrival at Mt. Zeppelin. Figure 1 gives an overview of the geographic areas, which were covered by 1-, 2-, and 5-day back trajectories to Mt. Zeppelin during the 10 years of the present study, covering the months March through October.

\subsection{Marine biological data}

The biologically active marginal-ice zone is a major natural source of sulfur in the Arctic summer atmosphere (Leck and Persson, 1996a, b), and Wiedensohler et al. (1996) indicated a potentially important role of dimethyl sulfide (DMS) in regional new particle formation. DMS emissions from the sea have long been proposed to control new particle formation in the marine boundary layer (Charlson et al., 1987), which builds on $\mathrm{DMS}_{\mathrm{aq}}$ being transported via turbulence and diffusion to the sea-air interface, represented by the transfer velocity, which in turn depends on sea surface temperature, salinity, and wind speed (Liss and Merlivat, 1986). Once in the atmosphere $\mathrm{DMS}_{g}$ is photochemically oxidized via intermediates such as sulfuric acid and methane sulfonic acid (Ayers et al., 1996), which eventually leads to the formation of aerosol $\mathrm{nsSSO}_{4}^{2-}$ and MSA. The products of the photochemical oxidation of DMS the ratio MSA / $\mathrm{nsSSO}_{4}^{2-}$ show a temperature dependence (Bates et al., 1990) favoring MSA in the cold Arctic environment (Karl et al., 2007).

Dimethyl sulfide in the ocean $\left(\mathrm{DMS}_{\mathrm{aq}}\right)$ is produced through the degradation of its algal precursor dimethylsulfoniopropionate (DMSP) by microbial food webs (Simó, 2001). At high latitudes, total DMSP (DMSPt), and therefore $\mathrm{DMS}_{\mathrm{aq}}$, essentially follows the seasonal cycle of phytoplankton biomass (Lana et al., 2012). DMSPt is defined as the sum of DMSP dissolved and DMSP $_{\text {particulate }}$ concentration. Yet, the amount of DMSPt per unit phytoplankton biomass may vary depending on species composition and physiological state (Keller et al., 1989).

The dissolved organic carbon (DOC) concentrations in surface waters of the high Arctic Ocean are up to 10 times higher than in any other ocean basin and closer in range to DOC levels reported for sea ice (Gao et al., 2012). A large fraction of DOC spontaneously assembles into polymer gels: polysaccharide-forming hydrated calcium bonded three-dimensional networks to which other organic compounds, such as proteins and lipids, are readily bound. The assembly and dispersion of the polysaccharide molecules can be affected by environmental parameters, such as UV-B radiation (280-320 nm) dispersing or inhibiting gel formation, and/or $\mathrm{pH}$ and temperature inducing gel volume phase changes (swelling and shrinkage). In the study of Orellana et al. (2011b), the swelling and shrinking of the polysaccharide networks or polymer gels were also causally related by additions of nano- to micromolar levels of DMS and DMSP. High DMSP concentrations have also been measured in the mucilage surrounding prymnesiophyte $P$ haeocystis pouchetii 
colonies in Arctic waters, representing up to $25 \%$ of the total water column DMSP pool (Matrai and Vernet, 1997).

The findings made by Orellana et al. (2011b) were in agreement with previous findings by Orellana et al. (2011a) that high concentrations of DMSP and DMS are stored in the acidic secretory vesicles of the Phaeocystis algae where DMSP is trapped within the condensed polyanionic gel matrix until the secretory vesicles are triggered by environmental factors such as temperature to release gels that undergo volume phase transition and expand at the higher $\mathrm{pH}$ of seawater. Exocytosis of polymer gels accompanied by elevated DMS and DMSP concentrations suggests the transport of these chemical compounds by the gel matrix. Schoemann et al. (2005) reported that Phaeocystis antarctica is particularly well adapted to low temperatures, being more competitive than $P$. pouchetii for temperatures between -2 and $+2{ }^{\circ} \mathrm{C}$. Phaeocystis pouchetii, however, appears to be better adapted to temperatures closer to $5^{\circ} \mathrm{C}$. In the Arctic a higher occurrence of the Phaeocystis pouchetii would be expected in the northward advection of warm Atlantic water masses around Svalbard.

Here we estimated DMSPt at the sea surface using the algorithm described by Galí et al. (2015). The DMSPt algorithm exploits the distinct relationship between DMSPt and Chlorophyll $a$ depending on the light exposure regime of the phytoplankton community. The light exposure regime is defined by the ratio between euphotic layer depth and mixed layer depth $\left(Z_{\mathrm{eu}} / \mathrm{MLD}\right)$. Additional predictor variables used are sea surface temperature (SST) and particulate inorganic carbon (PIC), which is used in the algorithm as a proxy for coccolitophores such as Emiliania huxleyi. During late bloom stages, the calcite plates that cover coccolitophore cells (called coccoliths) detach and cause an increase in seawater backscatter that invalidates satellite retrievals of Chlorophyll $a$. Therefore, inclusion of PIC in the algorithm as a proxy for DMSPt increases data coverage. Although the algorithm was developed for the global ocean, validation results with in situ data indicate that it performs as well or slightly better in Arctic and sub-Arctic waters.

The use of remotely sensed DMSPt as a proxy for marine DMSaq emission is a significant improvement with respect to prior studies that used Chlorophyll $a$ (Becagli et al., 2016; Zhang et al., 2015). Yet, it is not ideal because (i) the ratios $\mathrm{DMS}_{\mathrm{aq}} / \mathrm{DMSPt}$ in surface seawater are variable, and tend to be higher in high solar irradiance and nutrient-poor conditions typical of summer (Galí and Simó, 2015), and (ii) even if DMSPt is a better proxy for $\mathrm{DMS}_{\mathrm{aq}}$, the influence of meteorological and sea surface conditions (mainly wind speed and SST) on the sea-air flux of $\mathrm{DMS}_{\mathrm{aq}}$ is not taken into account. Development is underway of an algorithm for the retrieval of $\mathrm{DMS}_{g}$ concentrations in air and DMS fluxes.

The DMSPt algorithm was run for the 2006-2015 period using daily composites of the Moderate Resolution Imaging Spectroradiometer on the Aqua satellite (MODIS-Aqua) at $4.64 \mathrm{~km}$ resolution (L3BIN, reprocessing R2014.0) down- loaded from NASA's Ocean Color website (http://oceancolor. gsfc.nasa.gov). The MODIS variables used include Chlorophyll $a$ concentration derived with the Garver-SiegelMaritorena (GSM) algorithm (Maritorena et al., 2002), PIC, nighttime SST, and $Z_{\text {eu }}$. MODIS nighttime SST was complemented with SST from the Advanced Very High Resolution Radiometer (AVHRR; https://podaac.jpl.nasa.gov/ AVHRR-Pathfinder) to increase data availability. MLD was obtained from the MIMOC climatology (Schmidtko et al., 2013), which was linearly interpolated from its original $0.5^{\circ} \times 0.5^{\circ}$ grid at monthly resolution to the MODIS grid at daily resolution.

Satellite remote sensing of biological activity in surface waters requires ice-free and at least part of the time cloudfree conditions. The passive sensing methods of MODIS additionally require a minimum of solar illumination of the scenes (i.e., solar zenith angle $<70^{\circ}$; IOCCG, 2015). Consequently, the length of the satellite-observable period used to compute DMSPt means shortens from all year round at latitudes $<45^{\circ}$ to approximately 6 months (the spring-summer semester) at $80^{\circ} \mathrm{N}$. In addition, the annual DMSPt map in Fig. 3 excludes all land and ice-covered regions. In order to increase data coverage, daily DMSPt composites were binned to 5-day periods and a $46.4 \mathrm{~km}$ equal-area sinusoidal grid $(10 \times 10$ bins of the original pixel size). The average distance between a trajectory point and the closest center of a MODIS pixel is $18 \mathrm{~km}$.

Following the same approach as with the ice data average DMSPt from ocean color data (OC) along each back trajectory were calculated and will be referred to as OC1 (the last day), OC2 (the last but 1 day), and OC5 (days 3 to 5) before arrival at Mt. Zeppelin. In this procedure missing data were flagged as such, and were not taken into account.

\subsection{Ice data}

For the interpretation of events of new particle formation observed during the Oden cruises information on pack ice extent under the air masses reaching the sampling points proved crucial (Heintzenberg et al., 2015). Another motivation for utilizing ice data in the present study is the fact that the Svalbard region experiences large seasonal changes in pack ice cover which we expect to have strong effects on emissions of particles and their precursor gases. Thus, daily sea ice concentrations from Nimbus-7 SMMR and DMSP SSM/ISSMIS passive microwave data were taken from the NSIDC database (https://nsidc.org/data). The irregularly shaped data gap around the pole caused by the inclination of satellite orbits and instrument swath was filled with $100 \%$ cover. To each hourly position and data of the back trajectories, the ice information in the corresponding maps of ice concentrations were added and displayed in Fig. 2. On average the closest pixel in the ice maps was about $12 \mathrm{~km}$ off any trajectory point. 


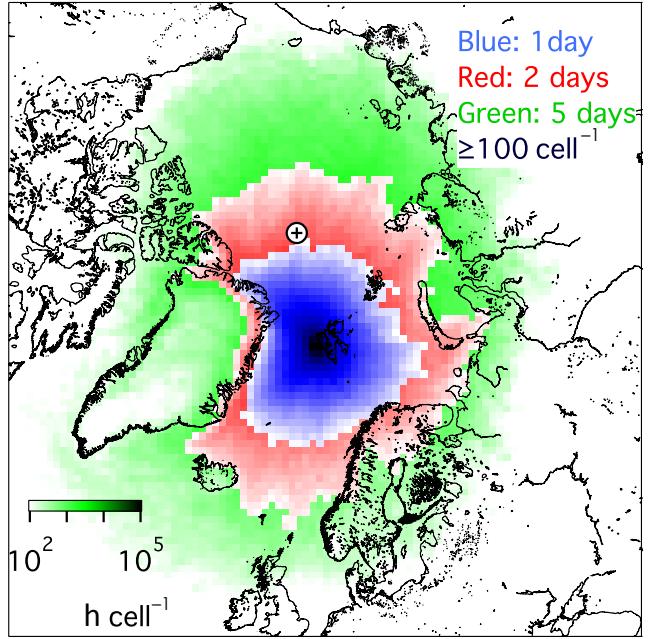

Figure 1. Map of the regional distribution of 5-day (green), 2-day (red), and 1-day (blue) hourly back trajectories to Mt. Zeppelin during the months March through October of the years 2006-2015. Black cross in a circle: North Pole. The colored areas are covered with at least 100 trajectory hours per geocell and the color saturation corresponds to the number of trajectory hours per grid cell on a log scale.

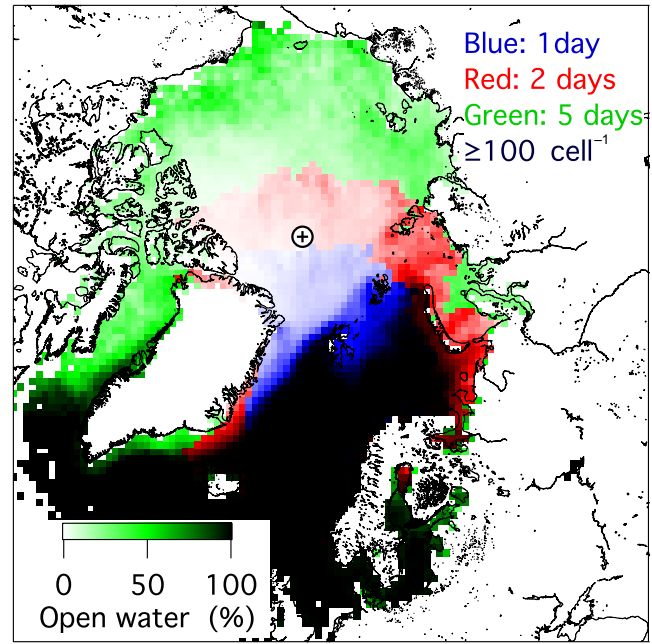

Figure 2. Map of the regional distribution of open water under 87648 5-day (green), 2-day (red), and 1-day (blue) hourly back trajectories to Mt. Zeppelin during the during the months March through October of the years 2006-2015. Black cross in a circle: North Pole. The areas are covered with at least 100 trajectory hours concurrent with data values per geocell.

In the discussion of results we utilize the complement of ice cover, i.e., the amount of open water because the marine biological processes of interest predominantly take place in the open water (Leck and Persson, 1996a). As integral parameters average open water $(\mathrm{OW})$, percentages along each back trajectory were calculated and will be referred to as OW1 (the last day), OW2 (the last but 1 day), and OW5

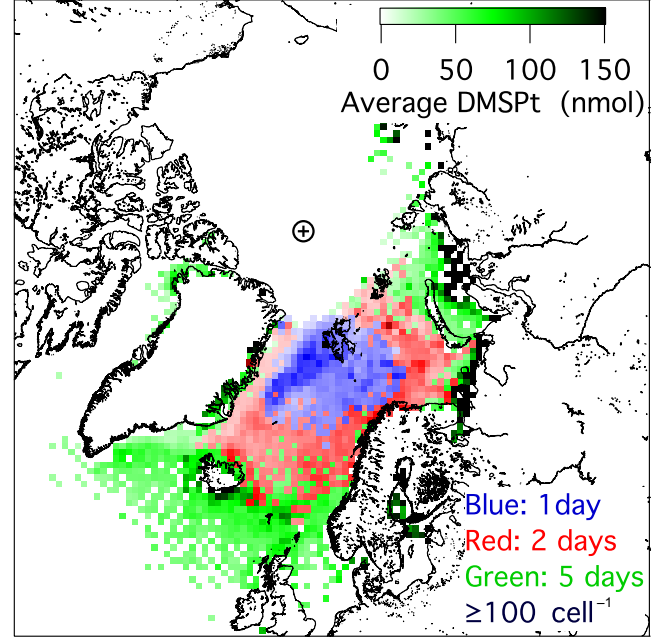

Figure 3. Map of the regional distribution of DMSPt along 87648 5-day (green), 2-day (red), and 1-day (blue) hourly back trajectories to Mt. Zeppelin during the during the months March through October of the years 2006-2015. Black cross in a circle: North Pole. The relative color scale holds for all colors. The areas are covered with at least 100 trajectory hours with data values per geocell.

(days 3 to 5) before arrival at Mt. Zeppelin. The most solid ice cover is seen in an area reaching from northeastern edge of Greenland via North Pole to Parry Island. A marginal-ice zone extends along the east coast of Greenland to Franz Josef Land, and the area between Svalbard and the latter island.

\subsection{ERA-Interim data of sea surface temperature}

Daily SST data for our study period (2006-2015) were downloaded from the website of the European Centre for Medium-Range Weather Forecasts (ECMWF). A description of the global atmospheric reanalysis (ERAInterim) has been given by Dee et al. (2011), and a guide to the products and the download procedures can be found at http://www.ecmwf.int/en/elibrary/ 8174-era-interim-archive-version-20. Briefly, ERA-Interim is an assimilating model reanalysis of the global atmosphere and sea surface physical parameters that has covered the data-rich period since 1979. SST data were downloaded at a resolution of approximately $0.56^{\circ}$ and regridded onto the same $46 \mathrm{~km}$ equal-area sinusoidal grid used for DMSP and cloud fraction (see below). Ice-covered pixels were screened out prior to the back-trajectory analysis. In the Arctic region, ERA-Interim has been shown to be a top performer among a number of atmospheric reanalyses (Lindsay et al., 2014).

\subsection{MODIS cloud fraction}

Persistent cloud cover limits PPP in Arctic and sub-Arctic seas (Bélanger et al., 2013) and, as mentioned above, irradiance at the sea surface, which is largely controlled by 
cloudiness, influences DMSP dissolved $_{\text {-to-DMS }}$ aq conversion. Boundary layer clouds are known to be additional controllers of the surface aerosol (Heintzenberg, 2012). In the summer Arctic low-level clouds and fogs are widespread (Warren and Hahn, 2002). Both scavenging and new particle formation have been observed in connection with low clouds and fog passages (Lannefors et al., 1983; Heintzenberg and Leck, 1994; Leck and Bigg, 1999; Heintzenberg et al., 2006; Karl et al., 2013). Beyond the cloud base derived from the ceilometer, we have no other in situ local or regional cloud information. Thus, we utilize satellite-derived cloud information.

Daily level-3 global cloud fraction with $1^{\circ}$ resolution was downloaded from NASA website (http://modis-atmos.gsfc. nasa.gov; Hubanks et al., 2015) and extracted for our region of interest. Briefly, level 3 images correspond to the aggregation of all level 2 images ( $1 \mathrm{~km}$ resolution) available within the $1^{\circ}$ resolution grid. For a given level 2 scene, each pixel is assigned a value of 1 (cloudy) or zero (clear sky), and then the individual scene values are averaged over a $24 \mathrm{~h}$ period. Note that a given pixel can be revisited up to 6 or 7 times in the course of a day at high latitudes. Finally, the daily composites were re-projected to $46.4 \mathrm{~km}$ pixels to match the spatial resolution of DMSPt. The average distance between a trajectory point and the closest MODIS pixel was $18 \mathrm{~km}$.

The cloud fraction (CF) as well as other cloud properties from MODIS have been extensively used, for instance, to study the global spatial and temporal distribution of clouds over the last decade (e.g., King et al., 2013). Several studies have also successfully performed validation by comparison with in situ data (e.g., An and Wang, 2015), which demonstrated the ability of the MODIS-aqua sensor to retrieve cloud cover.

Following the same approach as with the ice data and DMSPt, average cloud fractions (see Table 1) along each back trajectory were calculated and will be referred to as CF1 (the last day), CF2 (the last but 1 day), and CF5 (days 3 to 5) before arrival at Mt. Zeppelin. Missing data are flagged as was done with DMSPt data.

\section{Three approaches to identifying events of new particle formation}

There are no definitive and no generally accepted methods to identify or predict NPF events in atmospheric time series of aerosol data. Thus, in the present study we explored different approaches with varying degrees of complexity to identify such events. We emphasize that none of these approaches explicitly is connected to diel cycles such as in Dal Maso et al. (2005) or makes any assumptions about the time of day during which new particle formation occurs. Three objective search algorithms were written in FORTRAN to analyze the time series of hourly records of aerosol parameters in search of new particle formation:
1. The simplest approach of upper percentiles (PCT (percentiles) approach), assumes that NPF events are characterized by extremely high concentrations of small particles in terms of $N 25$ (see Table 1). The key parameter characterizing each PCT event was the value of $N 25$ averaged over a fixed number of hours $\left(N 25_{\mathrm{av}}\right)$ after the nominal start of an event (see below). With $N 25_{\mathrm{av}}$ also a nominal length of PCT events was defined as the number of hours after the start of an event by which $N 25$ sank to less than half of $N 25_{\mathrm{av}}$.

2. The more specific approach of diameter growth (DGR (diameter growth) approach) builds on the temporal development of the particle size distribution in terms of a systematic growth of the diameter D50 (see Sect. 4.1) to find the classical banana type of NPF event (Kulmala et al., 2004). The key parameter characterizing each DGR event was the average growth of $D 50$ during the nominal event length NUC (see below). For this approach the nominal length of events was reached when the running $2 \mathrm{~h}$ average growth fell below the value 1 .

3. The most complex approach of multiple-size events (MEV (multi-size growth) approach) searches for events with concurrent appearance of concentration increases in several size classes below $60 \mathrm{~nm}$ diameter (Karl et al., 2013; Leck and Bigg, 2010). The key parameter characterizing each MEV event was the relative concentration increase averaged over the chosen size classes below $60 \mathrm{~nm}$ during the nominal event length NUC (see below). As with PCT events a nominal length of MEV events was defined as the number of hours after the start of an event by which $N 25$ sank to less than half of $N 25_{\mathrm{av}}$.

Three time-related parameters were commonly defined for all three approaches:

1. Nominal NPF event length (NUC) was $9 \mathrm{~h}$.

2. Pre-event periods (PRENUC), from which increases in diameters or number concentrations were calculated, were $6 \mathrm{~h}$.

3. Reference periods (REF), before PRENUC and after NUC periods, were defined in order to compare event and pre-event data with non-event conditions. Each of these reference periods had the length of half the sum of pre-event plus event time periods, making the total reference time period of each event as long as that of the event itself.

Besides these common characteristic lengths individual fixed thresholds were chosen and discussed below for each approach in order to generate at least 200 unique events per approach (see Table 2).

The aerosol data used to define the NPF events were complemented by a large number of environmental parameters. 
Table 2. Total and unique number of events of new particle formation identified by the three approaches to identify NPF events, and percent of all data hours covered by unique events.

\begin{tabular}{llllll}
\hline Approach & Acronym & $\begin{array}{l}\text { Criteria and } \\
\text { thresholds }\end{array}$ & $\begin{array}{l}\text { Total number } \\
\text { of events }\end{array}$ & $\begin{array}{l}\text { Number of } \\
\text { unique events }\end{array}$ & $\begin{array}{l}\% \text { of total number } \\
\text { of data hours }\end{array}$ \\
\hline Percentiles & PCT & N25 $>93 \%$ percentile & 4143 & 240 & 1 \\
$\begin{array}{l}\text { Diameter growth } \\
\text { Multi-size growth }\end{array}$ & DGR & $\begin{array}{l}\text { DEV Growth }>1.5 \\
\text { Multi-growth }>1.6\end{array}$ & 1199 & 235 & 3 \\
\hline \multicolumn{7}{c}{ Sum } & & 6533 & 266 & 4 \\
\hline
\end{tabular}

The primary temporal resolution of the environmental parameters was between $1 \mathrm{~min}(C 25$; cf. Table 1$)$ and 5 days (DMSPt; cf. Table 1). C25 was calculated as $25 \%$ percentile on an hourly basis. The parameters with resolutions higher than an hour (OW, CF, and OC; cf. Table 1) were evaluated along the hourly back trajectories. While this procedure yielded hourly varying results even of $\mathrm{OW}, \mathrm{CF}$, and $\mathrm{OC}$ it has to be kept in mind that this hourly variability is the result of hourly resolved trajectories traversing the grid; the low primary temporal resolutions of the $\mathrm{OW}, \mathrm{CF}, \mathrm{OC}$, and chemical parameters remain. For these slowly varying parameters the REF periods before and after the events were extended to 1 day beyond the longest primary resolution, i.e., 6 days.

For two reasons the three search algorithms may yield temporarily redundant results; i.e., they may identify the same events. One, they go independently through the same time series of aerosol data, possibly causing inter-approach redundancy. Two, each algorithm goes through the time series hour by hour, thus allowing for temporal overlap of events found by each approach (intra-approach redundancy).

The three types of events were assumed to be mutually exclusive and potentially being caused by different sets of conditions for new particle formation. Thus, a FORTRAN procedure was developed to eliminate both intra- and interapproach redundancy while maintaining a maximum of identified NPF events. To remove intra-approach redundancy the procedure identifies overlapping events within each approach. Of each ensemble of such overlapping events the one with the strongest key parameter of the respective approach (growth of D50, or concentration increases as defined above) is retained. Next, inter-approach redundancy is addressed by the procedure. However, there is no unique solution to the problem of the partly redundant three time series of events. In order to avoid any preference of one or several types of events in the tests of inter-approach overlap pairs of events of different approaches are chosen at random and compared for overlap. This random comparison is done as often as the product of the number of events of the three approaches. This rather time-consuming random test yields stable numbers of non-overlapping events within less than $1 \%$, irrespective of the order in which the events of the three approaches were arranged for the test. By removing intra- and inter-approach redundancy in the first two steps of the procedure, a num- ber of time periods will be "freed". Consequently, in a last step, the procedure tries to fill the "freed time periods" nonredundantly with events of the three approaches that had been eliminated in the first two steps. Table 2 collects total numbers and unique numbers of events for each approach. In the rest of the paper only non-redundant events will be discussed. The total number of new particle formation events will be shortened to TNPF.

\subsection{The upper percentile of N25 (PCT approach)}

Events of new particle formation were identified by time periods in which $N 25$ was consistently, i.e., on average for $3 \mathrm{~h}$, above a set threshold. With a threshold of the $93 \%$ percentile $\left(170 \mathrm{~cm}^{-3}\right) 4143$ PCT events were identified in the total data set, only 240 of which were unique because most of them overlapped with event or pre-event times of the other two approaches. Average N25 during these unique events was $330 \mathrm{~cm}^{-3}$ and the average length of events $4 \pm 0.9 \mathrm{~h}$ (1 standard deviation).

Figure 4 (top) shows the average temporal development of the relative size distributions for the unique PCT events as in the results in Karl et al. (2013); i.e., relative concentrations were formed by dividing the absolute number concentrations by the average total number during the $6 \mathrm{~h}$ pre-event time periods. The events are characterized by a nearly monomodal distribution around $20 \mathrm{~nm}$ that broadens somewhat around the nominal start of the events. During the last $3 \mathrm{~h}$ before the events $D 50$ decreased slightly and returned to the pre-event level during the 9 NUC hours.

In connection with PCT events, average aerosol parameters NTO through $N 300$ showed an average increase by a factor of 2.2 during PRENUC periods, which was maintained on an average level of 1.5 during the events. The aerosolchemical parameters $\mathrm{Na}^{+}, \mathrm{nssSO}_{4}^{-2}$, and MSA were on an average level of $20 \%$ of their reference value. The average environmental parameters indicate a strong increase by a factor of 14 in solar radiation and a lifting of cloud base before the events. During the events the level of solar radiation was still elevated by a factor of 6 above its reference value. As a consequence temperature at the station was up by $2-3^{\circ}$. Precipitation $12 \mathrm{~h}$ before trajectory arrival time (SP12) was a factor of 5 above reference levels for air arriving during NUC 


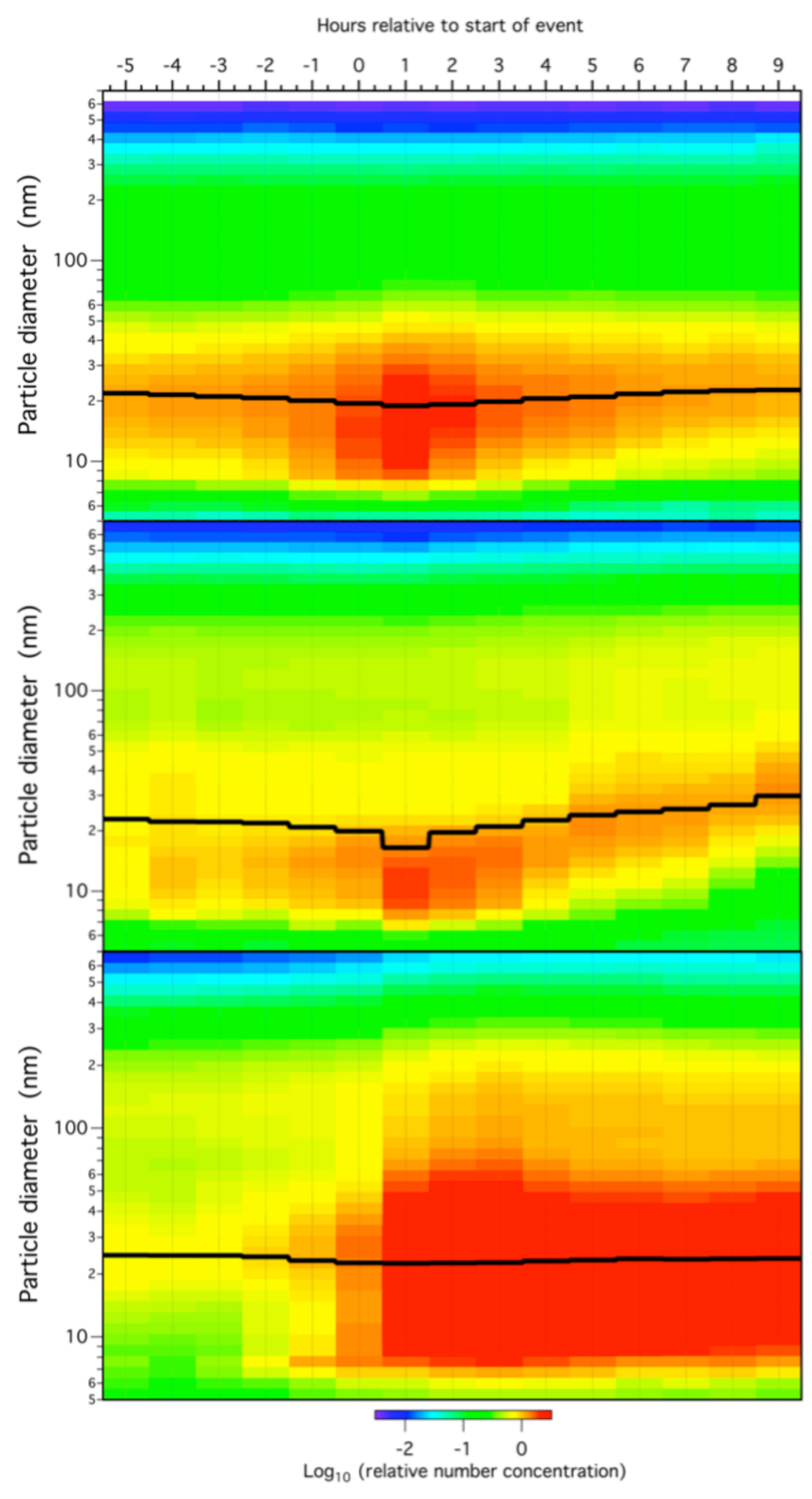

Figure 4. Average temporal development of the relative numbersize distribution before and during NPF events identified by the three approaches. Relative number concentrations are formed by dividing absolute number concentrations by the average total number during the $6 \mathrm{~h}$ pre-event time periods. The black curve gives the median sub-50 nm particle diameter D50 during the events. Top: PCT events; center: DGR events; bottom: MEV events.

periods, whereas SP35 to SP5D were below their respective reference levels. Cloud fractions were slightly raised $12-48 \mathrm{~h}$ before air arrival. Of the ocean parameters more open water was met by trajectories 12 to 24 before their arrival with ocean temperatures 12 to $48 \mathrm{~h}$ before trajectory arrival having been up to $4^{\circ}$ warmer than their respective reference values. On average DMSPt parameters OC24 through OC5D showed were raised by a factor of 2 above their reference value.
In Fig. 5 (left top panel), average trajectory height profiles during PRENUC and NUC periods are displayed. Widely varying vertical air mass paths occurred before and during PCT events. Median vertical trajectory paths during PRENUC and NUC times indicated air coming from some $300 \mathrm{~m}$ above station level 5 days ago sinking to about $100 \mathrm{~m}$ above station level during the last 2 days before arrival. The upper quartiles of the PCT height profiles point at strong subsidence before air mass arrival.

The right top panel in Fig. 5 maps average horizontal trajectory positions in $12 \mathrm{~h}$ steps in months having at least 10 PCT events, i.e., May-September. Filled circles around the trajectory positions comprise $95 \%$ of all events. The monthly average horizontal trajectory direction during PCT events mostly was from the northwest. In June and July the trajectories reached farthest into the multi-year ice cover northeast of Greenland. Only during September the back trajectories covered ice-free and marginal-ice areas in the Fram Strait. We note that the 5-day back trajectories of PCT events (and of the other two approaches as well) stayed within some $800 \mathrm{~km}$ of Mt. Zeppelin.

\subsection{The diameter growth (DGR) approach}

The DGR approach to identify events of new particle formation builds on the classical concept of particle growth through condensable vapors after an initial nucleation of sub-5 nm particles that cannot be observed with the available instrumentation, i.e., banana type (Kulmala et al., 2004). The respective algorithm utilizes the parameter D50 (see Table 1) and requires a growth of this diameter by at least a factor of 1.5 after the nominal start of an event. With this threshold the algorithm searched through all $87646 \mathrm{~h}$ of the 10 -year record and found 1199 DGR events of new particle formation. After eliminating cases of temporal overlap with the other two approaches 235 unique events of this type remained (see Table 2). Other or more DGR events could have been found by shortening the nominal 9 NUC hours. For two reasons we refrained from discussing shorter growth periods in the DGR approach. Maintaining common length NUC periods facilitated the comparison of results of the three approaches. Furthermore, reducing the growth period would also make PCT and DGR events ever more similar.

In the analysis of atmospheric data and theoretical modeling of NPF events of type DGR, two key parameters are discussed, namely particle formation rate $\left(J ; \mathrm{cm}^{-3} \mathrm{~s}^{-1}\right)$ and growth rate $\left(\mathrm{GR} ; \mathrm{nm} \mathrm{h}^{-1}\right)$ of particle diameters. For both parameters the measurement protocol by Kulmala et al. (2012) provides specific calculation procedures (Eqs. 2, 7, and 9), which we follow in the present study, albeit with the caveat that the $1 \mathrm{~h}$ temporal resolution of our time series is far below the 10 min time resolution that the protocol of Kulmala et al. (2012) requests in order to be able to follow the rapid development of NPF events. Furthermore, only the 127 DGR 


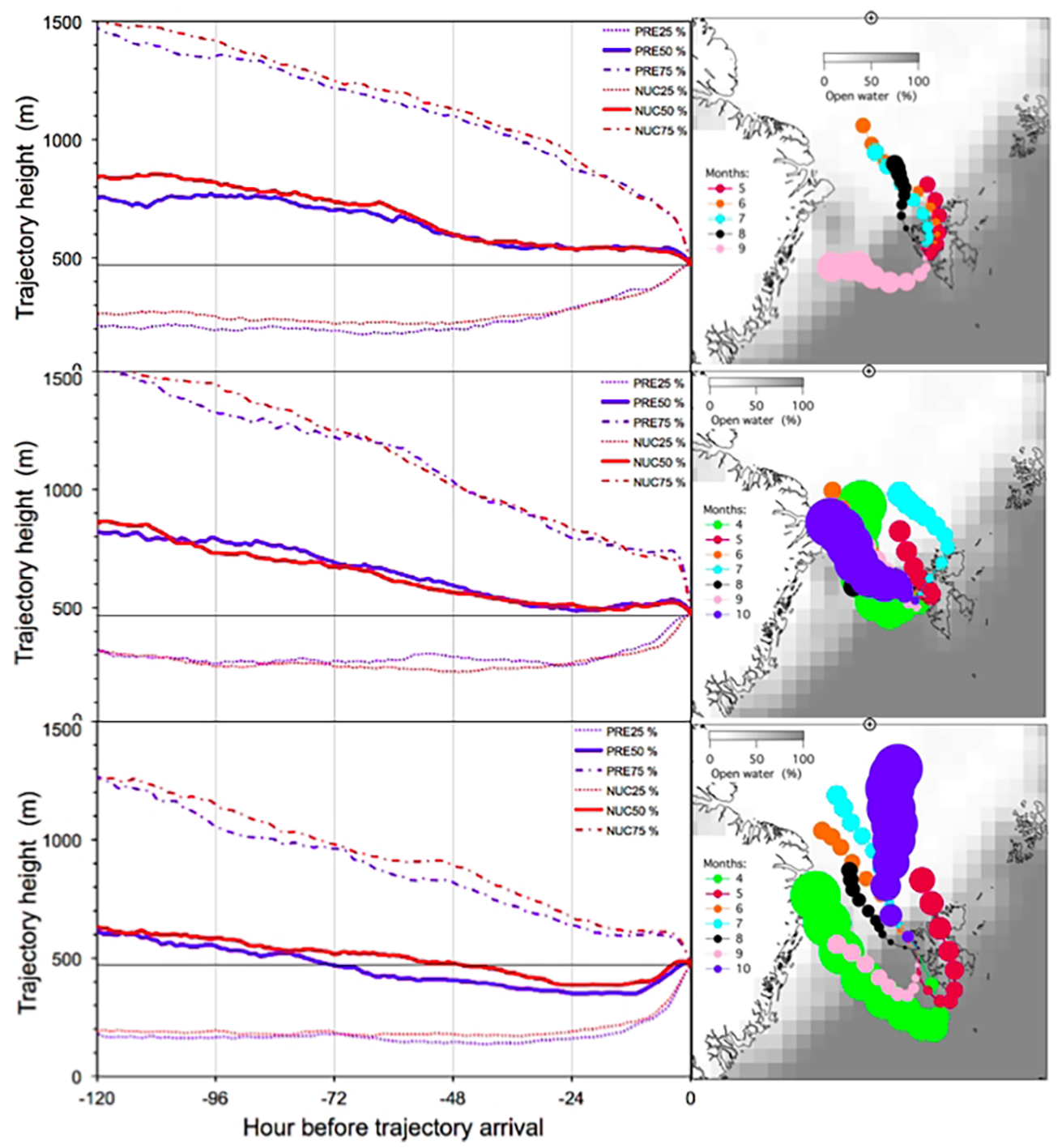

Figure 5. Left panels: median back-trajectory height profiles (m) during the 6 pre-event hours (full line in blue, PRENUC) and during the 9 DGR event hours (full line in red, NUC); 25 and $75 \%$ percentiles are shown as dotted and dash-dotted lines, respectively. Top: PCT events; center: DGR events; bottom: MEV events. The thin horizontal line marks the station level. Right panels: average monthly trajectory positions in $12 \mathrm{~h}$ steps for the months April though October. Only months with at least 10 NPF events are shown. The circles comprise $95 \%$ of all trajectories at any trajectory step. The underlying grayscale map indicates July ice cover averaged over the years 2006-2015.

events identified from 2011 on are based on particle size distributions measured down to a diameter of $5 \mathrm{~nm}$.

The sizes of newly nucleated aerosol particles are on the order of $1-2 \mathrm{~nm}$, which is below or near the limit of existing measurement techniques. When the nuclei grow in size their number concentration decreases because of various removal mechanisms. Instead of particle formation rates at the initial nucleus size apparent nucleation rates $J x$ are often reported, i.e., rates at which new particles appear at some larger observable particle diameter $\mathrm{d} x$. For the present study two apparent nucleation rates are calculated: DGR events of the whole time series have been identified with particle size distributions measured at diameters from $10 \mathrm{~nm}$ up through the growth of the number median diameter $D 50$ in the size range $10-50 \mathrm{~nm}$. Thus, we calculated $J 22$ for these 235 events at the nominal geometric mean diameter of $22 \mathrm{~nm}$. For 127 of these events size distributions reached down to $5 \mathrm{~nm}$ diameter (years 2011 and later). For these events we calculated $J 11$ at the geometric mean diameter $11 \mathrm{~nm}$ as representative for the diameter range $5-25 \mathrm{~nm}$, which is close to the frequently reported apparent formation rate $J 10$ at $10 \mathrm{~nm}$ diameter. Additionally, the two corresponding grow rates GR22 and GR11 were calculated in the respective diameter ranges.

Statistics of these four key parameters of the DGR events are collected in Table 3. 
Table 3. Statistics of particle formation rates of DGR events $J 11$ and $J 22\left(\mathrm{~cm}^{-3} \mathrm{~s}^{-1}\right)$, at the nominal geometric mean diameters $11 \mathrm{~nm}$, and $22 \mathrm{~nm}$ and corresponding diameter growth rates GR11, and GR22 $\left(\mathrm{nm} \mathrm{h}^{-1}\right)$ in the two diameter ranges $5-25 \mathrm{~nm}$, and $10-50 \mathrm{~nm}$.

\begin{tabular}{lllll}
\hline Statistics & $J 11$ & GR11 & $J 22$ & GR22 \\
\hline Minimum & 0.1 & -1.2 & 0.1 & -0.1 \\
$25 \%$ & 0.4 & 0.1 & 0.2 & 1.0 \\
$50 \%$ & 0.7 & 0.4 & 0.3 & 1.4 \\
$75 \%$ & 1.4 & 0.6 & 0.7 & 1.8 \\
Maximum & 19 & 2.2 & 22 & 4 \\
\hline
\end{tabular}

Depending on the pollution level at the measuring site widely varying values of $J 10$ have been reported. For the polluted sub-tropical environment of Taiwan, Young et al. (2013) gave values from 4.4 to $30 \mathrm{~cm}^{-3} \mathrm{~s}^{-1}$, whereas Pierce et al. (2014) published values between 0.22 and $0.84 \mathrm{~cm}^{-3} \mathrm{~s}^{-1}$ from a rural Canadian setting. The latter range is within the range $0.1-9.4 \mathrm{~cm}^{-3} \mathrm{~s}^{-1}$ with a median value of $1.2 \mathrm{~cm}^{-3} \mathrm{~s}^{-1}$ reported by Yli-Juuti et al. (2009) for a station in rural Hungary. The two formation rates of the present study cover the range $0.1-1.4 \mathrm{~cm}^{-3} \mathrm{~s}^{-1}$ for the 25 to $75 \%$ percentiles (see Table 3), which covers the range of 0.05 to $0.13 \mathrm{~cm}^{-3} \mathrm{~s}^{-1}$ given by Venzac et al. (2009) for a remote site in the Himalayas. The environmental conditions at the Siberian station Tiksi at the coast of the Laptev Sea may come closest to our Arctic setting. From this site Asmi et al. (2016) published formation rates of 0.01 to 0.41 at an unspecified particle size.

$\approx n$ terms of 25 to $75 \%$ percentiles the particle growth rates of the present study range from 0.4 to $1.4 \mathrm{~nm} \mathrm{~h}^{-1}$ in the range $5-25 \mathrm{~nm}$ and 1.0 to $1.8 \mathrm{~nm} \mathrm{~h}^{-1}$ in the diameter range $10-50 \mathrm{~nm}$, which is near the range of results of $1-2 \mathrm{~nm} \mathrm{~h}^{-1}$ derived by Ström et al. (2009) for new particle formation in the lower boundary over Ny-Ålesund, Spitsbergen, but considerably lower than the maximum growth rate of $3.6 \mathrm{~nm} \mathrm{~h}^{-1}$ reported by Asmi et al. (2016) for July at the Siberian station Tiksi at the coast of the Laptev Sea. For open ocean new particle formation events over the North Atlantic, O'Dowd at al. (2010) reported a "typical growth rate" of $0.8 \mathrm{~nm} \mathrm{~h}^{-1}$, whereas Ehn et al. (2010) gave an average growth rate of $3 \mathrm{~nm} \mathrm{~h}^{-1}$. We note that the average length of DGR-events was $10 \pm 1 \mathrm{~h}$ ( 1 standard deviation). Further details about the connection between growth rates and the two formation rates can be found in the Supplement.

The average temporal development of the relative number-size distribution during DGR events is presented in Fig. 4 (center). After a decrease of the sub-50 nm diameter median from about 25 to $16 \mathrm{~nm}$ during the $6 \mathrm{~h}$ before the nominal start of the events $D 50$ increases systematically during the following 9 NUC hours with somewhat reduced growth towards the end of the event.
During the PRENUC periods, particle number concentrations $N 300$, and the condensation sink (CS) decreased relative to the reference periods before and after the events. Subsequently, during the NUC periods the strongest increases were found for N60. Environmental parameters around air mass arrival showed a strong lifting of cloud base (C25) and an extremely high increase in solar radiation (by a factor of 11 during PRENUC and by a factor of 60 during NUC periods). However, $12 \mathrm{~h}$ before air arrival precipitation had been up by a factor of 2.5. Cloud fractions were down to about $70 \%$ of their reference values 24 through $48 \mathrm{~h}$ before air arrival. Of the chemical aerosol parameters $\mathrm{Na}^{+}$and $\mathrm{nssSO}_{4}^{-2}$ showed an increase of 2.6 and 2.3, respectively. OC12 and OC48 were slightly higher than reference level before and during the events. Sea surface temperatures $T 24$ were raised by nearly $1 \%$, whereas earlier SST values $(T 36-T 5 \mathrm{D})$ were up to $1^{\circ}$ below reference values.

Figure 5 (left center panel) shows statistics of the vertical air movement before trajectory arrival during DGR events at Mt. Zeppelin covering a wide range of vertical movements between $200 \mathrm{~m}$ and beyond $1500 \mathrm{~m}$ height. During the days when elevated DMSPt levels were noted, median trajectory heights were $600-900 \mathrm{~m}$. Median trajectories during PRENUC times dipped down to the station level (474 m a.s.l), about 1 day before arrival, albeit lifted and subsided again shortly before arrival. Vertical trajectory pathways will be discussed further in Sect. 4.2.

Monthly average trajectory positions and their variability in connection with DGR events are shown in Fig. 5 (centerright panel). The months April through October had at least 10 DGR events per month. As with PCT events the general trajectory direction was from the northwest, mostly staying for several days over the marginal-ice zone between northeastern Greenland and eastern Svalbard. During the earliest month of April with 14 DGR events the back trajectories reached farthest south into the ice-free parts of the Fram Strait.

\subsection{The multiple-size approach (MEV)}

Leck and Bigg (2010) and Karl et al. (2012, 2013) discussed a type of new particle formation that to date only has been reported from the summer Arctic. During these MEV events, high ultrafine particle concentrations appear concurrently in a broad diameter range reaching from under 10 to some $60 \mathrm{~nm}$. We simulated this type in a search that required the concurrent increase of NTO, N20, N40, and N60 (cf. Table 1), as averaged over the first 3 NUC hours by a factor $\geq 1.6$ over their respective averages during the 6 (PRENUC) hours. Over the 10 years of data 1191 such events of this type were identified, 266 of which remained after removal of those overlapping with events of other approaches. During these unique events the average concurrent concentration increase was 4.7 and the average length of the events $12 \pm 0.8 \mathrm{~h}$. 
The concurrent appearance of high concentrations at many particle sizes below $60 \mathrm{~nm}$ resembles the nocturnal NPF events analyzed by Suni et al. (2008) in the Australian Eucalyptus forest and simulated in subsequent chamber experiments (Ristovski et al., 2010; Junninen et al., 2008). We emphasize though that the condensing vapors in the Australian NPF events originating from terrestrial biogenic emission are quite different from the polymer gels implicated in the Arctic $\mathrm{MEV}$ events and originating from the surface microlayer of the ocean.

The bottom part of Fig. 4 shows the average temporal development of relative number-size distributions before and during MEV events. The development before the nominal start of MEV events is more complex than during the PRENUC periods of the first two types of events. Intermittently a mode around $7 \mathrm{~nm}$ shows up that broadens and becomes more prominent about $2 \mathrm{~h}$ before the nominal start of events. The major PRENUC mode around $25 \mathrm{~nm}$ also broadens and becomes more prominent towards NUC. A weak mode exists during PRENUC around $120 \mathrm{~nm}$ and hardly any particles beyond $400 \mathrm{~nm}$. D50 sinks from 25 to about $20 \mathrm{~nm}$ and stays below $25 \mathrm{~nm}$ through the MEV events even though number concentrations increase during the first NUC hours by more than a factor of 5 .

During NUC periods all particle number concentrations increased, on average by a factor of 1.6. Average solar radiation also increased by about $90 \%$ above reference level during NUC periods. Of the chemical parameters $\mathrm{nssSO}_{4}^{-2}$ showed an increase by a factor of 3 during PRENUC and NUC periods, and MSA a slight increase during PRENUC periods. On one hand, precipitation $12 \mathrm{~h}$ and 36 to $48 \mathrm{~h}$ before trajectory arrival (SP12, SP48), were above reference levels for air arriving during PRENUC periods. On the other hand, during PRE, SP24, SP36, an SP5D indicated dry conditions during PRENUC and NUC periods. Only 3 to 5 days before air arrival slightly increased cloud fractions were noted. Sea surface temperatures up to 5 days before trajectory arrival were on average about $1^{\circ}$ lower than their reference values. DMSPt parameters OC12 to OC36 were raised by factors of 1.3 and 1.6 during PRENUC and NUC periods, respectively.

Percentiles of vertical trajectory coordinates prior to and during MEV events are displayed in Fig. 5 (bottom left panel). During the events, and even stronger during the PRENUC periods median trajectories had been below $500 \mathrm{~m}$ for more than 4 days. Furthermore, the final air approach to Mt. Zeppelin mostly came from below the station level. Upper quartiles of the vertical trajectory positions are substantially lower than with DGR events. We note, however, that a short excursion above station level occurred in the upper quartiles during the last $3 \mathrm{~h}$ before arrival.

The bottom right panel of Fig. 5 gives the monthly average trajectory positions and their variability in connection with MEV events. The months April through October had at least $10 \mathrm{MEV}$ events per month. As with the other approaches the general trajectory direction was from the northwest, albeit with stronger swings towards the ice-free areas south of Svalbard early and late in the season (April, May, and September). Interestingly, the trajectories of the $11 \mathrm{MEV}$ events in October were directed nearly straight north from the North Pole.

Summarizing differences and commonalities among the results of the three approaches, we can state that the length of the events increases from 4 to 10 and 12, going from PCT to MEV events. PCT events are characterized by lower-thanreference aerosol-chemical parameters. $\mathrm{Na}^{+}$and $\mathrm{nssSO}_{4}^{-2}$ show strong increases in the other two types of events: $\mathrm{Na}^{+}$ in connection with DGR events and $\mathrm{nsSSO}_{4}^{-2}$ in connection with MEV events. Both PCT and DGR events exhibit strong increases in solar radiation. Precipitation before air arrival was raised at varying times in connection with the three types of events. Cloudiness both increased and decreased at varying times before air arrival with the three types of events. Increased open water under the trajectories was strongest with DGR events and least important with MEV events. Only in connection with PCT events strongly raised sea surface temperature were noted before trajectory arrival. DMSPt-related ocean parameters were raised to varying degrees and at varying times before all NPF events, most strongly in connection with PCT events and least in connection with DGR events.

\section{Discussion}

\subsection{Environmental setting}

The discussion of the results on new particle formation in the Svalbard region builds on the variability of new particle formation and related environmental parameters on scales of months and days. Fig. 1 illustrates that air, arriving at Mt. Zeppelin during the 10 summers of the present study, came from widely varying regions from the central ice-covered Arctic via the northern seas and northernmost Scandinavia to Greenland; 1-day back trajectories cover a roundish area from the central east coast of Greenland via northern Scandinavia to Franz Josef Land, the North Pole, and back to the north coast of Greenland. Excluding inner Greenland this area is widened by roughly $500 \mathrm{~km}$ by 2-day back trajectories and by at least another $500 \mathrm{~km}$ by 5 -day back trajectories reaching over most of Greenland and the adjacent seas west of Greenland. This is a much wider region from which air may reach Mt. Zeppelin as compared to sites in the inner Arctic as illustrated in Fig. 2 of Heintzenberg et al. (2015).

On the path of trajectories to Mt. Zeppelin quite different ice conditions were met (see Fig. 2). On average North Atlantic open waters reached around western Spitsbergen all the way to Nordaustlandet. Drift ice was passed over by trajectories along the whole east coast of Greenland; 1-day trajectories passed over the marginal-ice zone from the Fram Strait to Franz Josef Land but also over more contiguous ice 
close to the North Pole. At times, with 5-day back trajectories, even the marginal-ice regions of Baffin Bay and Beaufort Sea were reached.

The long-term geographical distribution of DMSPt in Fig. 3 reflects the water conditions for phytoplankton biomass around Svalbard. Directly at the coasts of Greenland and Eurasia, increased nutrient availability in coastal and shelf waters (due to continental runoff and enhanced hydrodynamics) cause localized areas of high DMSPt values. The low DMSPt values further out along the coast of Greenland are due to sea ice reaching through the Fram Strait far south (see Fig. 2). A prominent feature in the regional DMSPt distribution is the tongue of high DMSPt (intense blue color) and thus high phytoplankton biomass east of this area, reaching from Spitsbergen to roughly Jan Mayen that lies within 1-day back trajectories. Northward-flowing Atlantic waters, carried by the West Spitsbergen Current, and southward-flowing fresh surface waters from melting ice, and recirculated Atlantic waters carried by the East Greenland Current (Rudels et al., 2005) are meeting. The layering created by water masses of different density stabilizes the water column and traps phytoplankton cells at well-lit depths. If sufficient nutrients are available, this can lead to the development of large phytoplankton blooms, which can result in high concentrations of $\mathrm{DMS}_{\mathrm{aq}}$ (see Fig. 2 in Leck and Persson, 1996a).

In the 10-year average cloud fractions systematic differences in cloudiness appear. Depending on transport pathways as identified by the back trajectories, cloudiness varies on the way to Spitsbergen. The ice-covered areas (cf. Fig. 2) from the east coast of Greenland to Franz Josef Land exhibit somewhat lower cloud fractions than the ice-free regions southwest to east of Spitsbergen.

\subsection{Seasonal variability}

Seasonal changes are discussed in terms of monthly averages taken over the 10-year study period. As expected in Earth's polar regions the seasonal variability of all environmental parameters is very high as exemplified by the solar flux (SFL) and the air temperature (TEM) at Mt. Zeppelin in Fig. 6. Due to the seasonal change in cloudiness (cf. Fig. 7), the seasonal distribution of SFL is not quite symmetrical about mid-summer but is skewed slightly towards the cloud minimum in spring. The air temperature, however, does not peak before July and has a broad shoulder into fall and winter. The first, and partly absolute maxima, of the seasonal distributions of NPF events in Fig. 6 coincide with that of the SFL but then drop of more slowly towards fall than solar radiation. In particular, MEV events do so and even have their main maximum in August. The occurrence of all NPF events drops off sharply in October. Whereas May as the first month with larger numbers of events is dominated by PCT events, followed by DGR and then MEV events, the contributions of

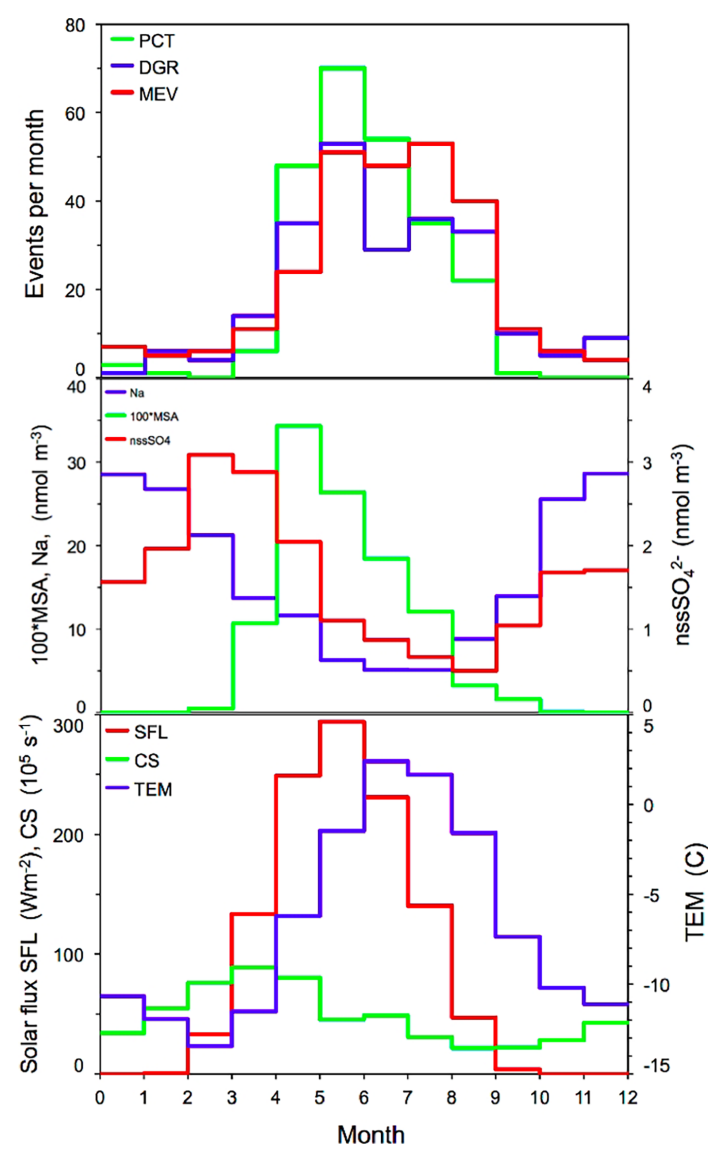

Figure 6. Top: monthly numbers of new particle formation events according to the three approaches, summed up over the whole period of 10 years. PCT: upper percentile of N25; DGR: diameter growth; MEV: multiple-size events. Center: average seasonal distribution of particle composition in $\mathrm{nmol} \mathrm{m}^{-3}$. $\mathrm{Na}=$ sodium, $\mathrm{nssSO}_{4}=\mathrm{nssSO}_{4}^{2-}, \mathrm{MSA}$ is methane sulfonate times 100. Bottom: monthly average solar flux (SFL; red, $\mathrm{Wm}^{-2}$ ), and temperature (TEM; blue ${ }^{\circ} \mathrm{C}$ ), and condensation sink $\left(\mathrm{CS} ; 10^{5} \mathrm{~s}^{-1}\right.$ ), at Mt. Zeppelin, Spitsbergen.

the three NPF types are reversed in the last month with high NPF numbers, i.e., September.

Figure 6 clearly shows that the formation of new particles in the Svalbard region is not controlled by the late winter to early spring phenomenon of Arctic haze peaking with highest sulfate concentrations in March (cf. Fig. 3 in Heintzenberg, 1989, and Fig. 6), which has a minimum in the total number of NPF events. This minimum is in contrast with the maximum in new particle formation rates found by Croft et al. (2016a) with their global aerosol model. The high numbers of accumulation mode particles during the Arctic haze months in late winter and spring yield the annual maximum in condensation sink (CS in Fig. 6), which could quench nucleation events and subsequent growth. Thus, even though photochemistry may produce significant amounts of nucleating material, the freshly formed particles will not grow to a 


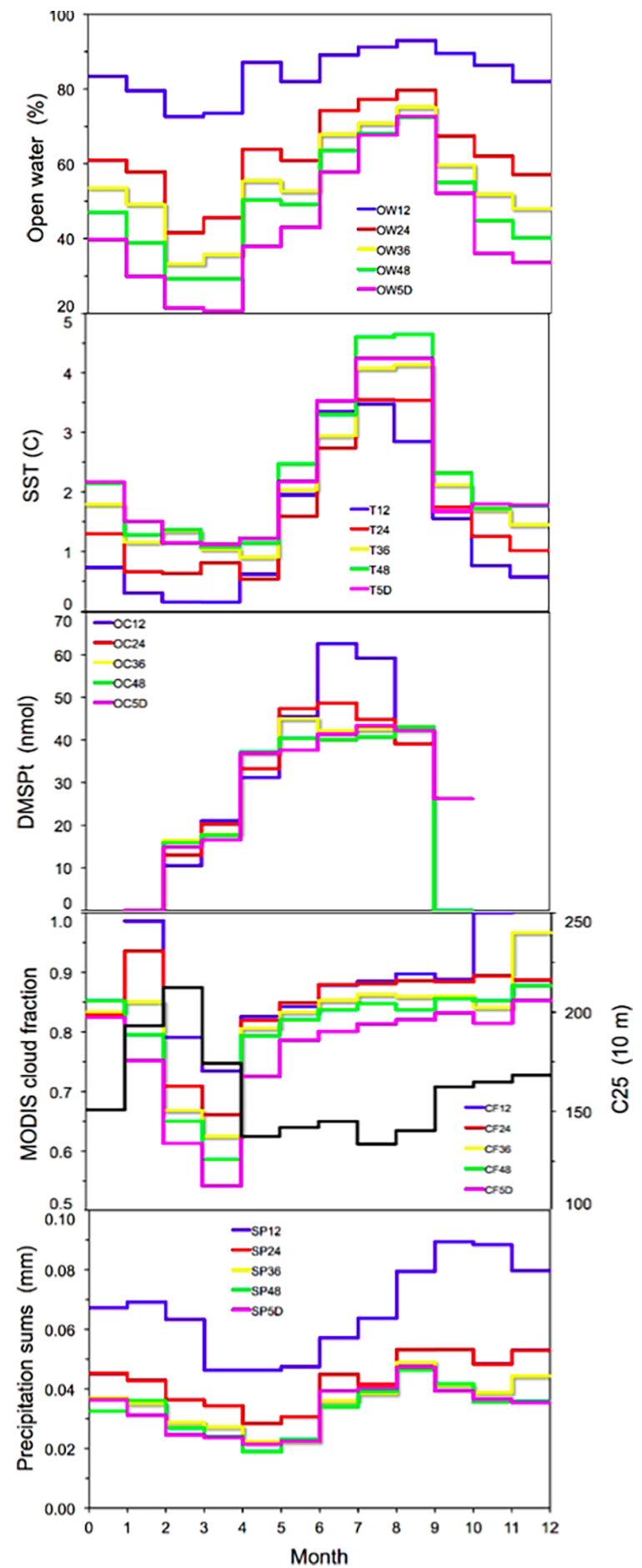

Figure 7. Monthly averages of environmental parameters averaged along back trajectories to Mt. Zeppelin. From top to bottom: OW125D: open water in $\%$ during last $12,24,36$, and $48 \mathrm{~h}$, and days 3-5 before trajectory arrival at Mt. Zeppelin. T12-5D: same for sea surface temperature in ${ }^{\circ} \mathrm{C}$. OC12-5D: same for DMSPt in nmol in surface waters. CF12-5D: same for MODIS cloud fraction. SP12-5D: same for precipitation sums in millimeters. $C 25=25 \%$ percentile of cloud base in decameter. stable size before they are removed via either deposition or coagulation as discussed by Tunved et al. (2013) and others. An alternative explanation of the late onset of NPF events in TNPF in spring lies in the marine biological processes not being activated nearby during the Arctic haze period yet (Heintzenberg and Leck, 1994).

Figure 7 collects the seasonal variation of environmental parameters as averaged along the back trajectories to Mt. Zeppelin. From their minimum in March-April, openwater conditions improve until September, after which the pack ice extent under the trajectories rapidly increases again. The widening open-water areas are reflected in sea surface temperatures under the trajectories that increase until September before they drop off strongly in October. Consequently, because of its connection to marine biological activity, DMSPt increases in the euphotic zone from first photosynthetic light in May until it evens out around July and drops off in October. The largest DMSPt values are reached in the vicinity of Svalbard (cf. OC12 in July and August in Fig. 7), i.e., considerably later than MSA. The ending of DMSPt curves in October is due to the lack of data not due to zero DMSPt. Still, DMSPt concentrations are expected to be low at this time of the year at temperate to polar latitudes due to low phytoplankton biomass and low light exposure (see Fig. 9 in Galí et al., 2015). In terms of the MODIS-derived cloud fraction, cloudiness increases rapidly from its minimum in April and evens out on a plateau of 80-90\% after July. The spring minimum in cloudiness is confirmed by the maximum in cloud base as indicated by $C 25$ in Fig. 7. This seasonal distribution of cloudiness does not correspond to the classical picture of near-surface cloudiness that exhibits nearcloud-free conditions in winter and mostly overcast with Arctic stratus and fogs during the summer months (Warren and Hahn, 2002; Huschke, 1969). We explain the difference by the specific atmospheric pathways covered by the back trajectories of the present study (cf. Fig. 1). Trajectoryaveraged precipitation parameters (SP12-5D in Fig. 7) have minima in the period April-May, from which they increase towards their maxima in fall and winter.

The chemical aerosol information derived from the analyses of filters samples has a relatively low temporal resolution of at least 1 day combined with frequent gaps of several days in between samples. Thus, it cannot directly be related to the time periods of NPF events. The seasonal distribution of chemical tracers, however, yields important information about new particle formation. Taken over the whole year nssSO $\mathrm{S}_{4}^{2-}$ in Fig. 6 is largely anthropogenic (Heintzenberg and Leck, 1994), and has its maximum during the peak of Arctic haze in March and April and its minimum in August, which does not match any seasonal distribution of NPF events. We also plotted $\mathrm{Na}^{+}$in Fig. 6 as a tracer of the inorganic marine aerosol components sea salt. $\mathrm{Na}^{+}$decreases from its winter maximum to its summer minimum in June/July, again without similarity to the NPF distributions. Instead, the seasonal distribution of $\mathrm{Na}^{+}$rather closely 


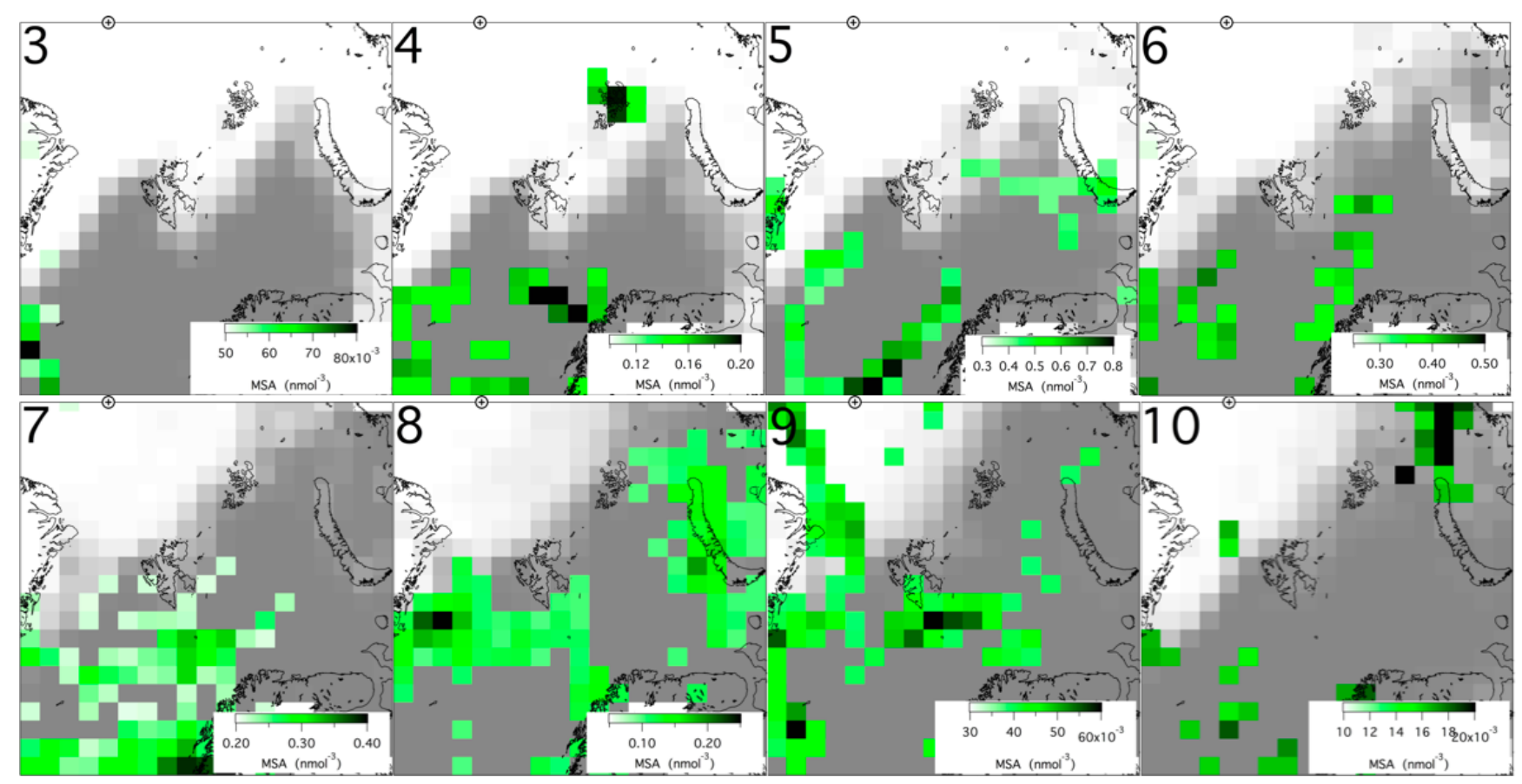

Figure 8. Average monthly distribution of methane sulfonic acid (MSA; nmol m ${ }^{-3}$ ), during the months March-October of the years $2006-$ 2015, constructed from MSA concentrations measured on Mt. Zeppelin, which were extrapolated along 5-day back trajectories. Average open-water percentages during the respective months are indicated as white $(0 \%$ open water) to dark gray ( $100 \%$ open-water) areas. The position of the North Pole is marked as a cross in a circle on the upper border of the maps.

follows that of the trajectory-derived wind speed during the last hour before arrival (not shown in the figure). Wind speed as driver for sea salt production is a well-established phenomenon (Blanchard and Woodcock, 1957). After a steep rise in April, MSA in Fig. 6 sharply peaks in May and then gradually drops off towards its minimum in October, more gradually than reported for data taken from 1991 to 2004 by Sharma et al. (2012) and earlier than reported by Heintzenberg and Leck (1994), both at the same station. Our seasonal distribution of MSA most closely resembles that of SFL, in Fig. 6, albeit with its peak in May a month earlier that SFL and more strongly skewed towards spring. According to Leck and Persson (1996b), on average the concentrations of the marine biogenic sulfur components (DMS and MSA) fell with a decline rate of about $30 \%$ per week approaching zero values in September explained by reduced PPP (Leck and Persson, 1996a) (consistent with Becagli et al., 2016).

As MSA is the only measured aerosol component with exclusively marine biogenic sources, we illustrate its seasonal distribution in greater detail in Fig. 8. In this figure MSA concentrations measured on Mt. Zeppelin have been extrapolated along 5-day back trajectories, forming monthly average monthly maps of potential MSA sources during the biologically most active months of March through October.

Figure 8 yields several pieces of information that are relevant to the issue of new particle formation. Early in spring the biological aerosol sources are limited to the North Atlantic and Norwegian Sea. In April the tongue of newly opened waters between Novaya Zemlya and Franz Josef Land seemingly is beginning to become biologically active. In May this area widens towards the Barents Sea while the North Atlantic also becomes more active, reaching the Fram Strait. In August two wide potential source regions cover the region from northern Greenland to the northern end of Scandinavia and the region Barents to Kara Sea. In September even the pack ice north of Svalbard becomes biologically active (Leck and Persson, 1996a) and shows potential MSA sources, in particular, north of the northern coast of Greenland. Finally, the very weak potential MSA sources in October appear to be situated mainly over the Kara Sea and over the North Atlantic.

How do these seasonal distributions compare to those of the NPF events identified by the three search approaches defined in Sect. 3? To address this question we constrained the average seasonal distribution of environmental parameters to those hours that had been identified by the NPF events of the three approaches. However, none of the individual seasonal distributions of constrained environmental parameters follows closely any of the NPF events. In particular, the main MSA peak remains in May, thus 1 month earlier than any peak of the NPF occurrences. To elucidate further potential differences in the three types of NPF events, we return to the discussion of vertical pathways of related back trajectories (see Fig. 5). In this figure all three types of NPF events exhibit a wide range of vertical trajectory paths. As we ex- 

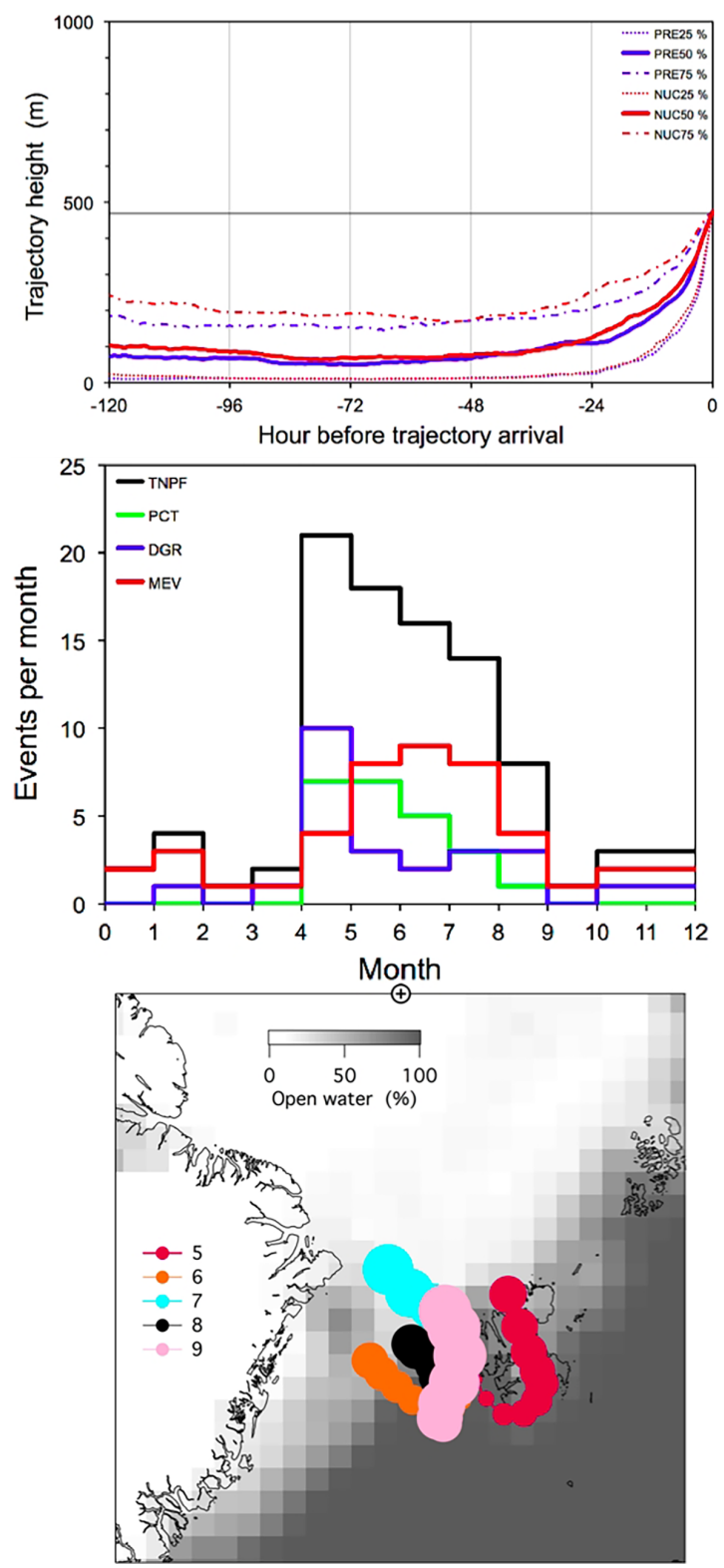

Figure 9. Characteristics of the sub-population of 93 NPF events with back trajectories that stayed below $500 \mathrm{~m}$ for 5 days before arrival. Top: statistics of related vertical trajectory coordinates as in Fig. 5. Center: average monthly occurrence of PCT, DGR, and MEV events, summed up over the whole period of 10 years. Bottom: related average monthly trajectory positions in $12 \mathrm{~h}$ steps for the months May through September. The circles comprise $95 \%$ of all trajectories at any trajectory step. The underlying grayscale map indicates July ice cover averaged over 2006-2015.

pect the regional sources of primary particles and particle precursors to be at or near the surface, we segregated the NPF events into sub-populations with back trajectories that remained a given time below $500 \mathrm{~m}$ (roughly station level). In Fig. 9 we collected the results concerning the 93 NPF events that occurred with trajectories under the $500 \mathrm{~m}$ limit, i.e., roughly $12 \%$ of all events. The top panel shows that the related trajectories not only stayed below $500 \mathrm{~m}$ through most of the last 5 days before arrival but also close to the surface until they started rising to the station level about $24 \mathrm{~h}$ before arrival. The peak of the sum of event occurrences now coincided with the main MSA peak in May (see center panel in Fig. 9). For DGR events, the May maximum was particularly strong, whereas the PCT predominantly occurred in May and June and MEV events remained clustered around the later part of summer, possibly coupled to SST and DMSPt.

A number of environmental parameters indicated substantial deviations from their respective reference values during the months with most frequent occurrence of this subpopulation of NPF events. Strongest deviations were noted for precipitation that was elevated above reference levels 2 to 5 days before trajectory arrival, most prominently for DGR events in May (by a factor of $636 \mathrm{~h}$ before trajectory arrival). Strong positive deviations in aerosol-chemical parameters only occurred with $\mathrm{Na}^{+}$in PCT and MEV events, indicating relatively high wind speeds near sea surface in the related air masses. MSA was elevated up to $50 \%$ above reference levels only during MEV events. Elevated levels of DMSPt were noted with all three types of NPF formation, most prominently for DGR events 12 to $36 \mathrm{~h}$ before which DMSPt was increased by a factor of up to 1.7 relative to reference levels.

The bottom panel of Fig. 9 gives average trajectory positions in $12 \mathrm{~h}$ steps for the months May through September. The circles around the steps comprise $95 \%$ of all trajectories. During all months the trajectories stayed in the ice-free and marginal-ice zone between Fram Strait and eastern Svalbard as illustrated by average July ice cover for the 10 study years (for average monthly ice covers cf. Fig. 8). In particular during the earliest and latest months of May and September the trajectories swing farthest south over the open water south of Svalbard. We note that the complementary sub-population of results with trajectories remaining above station level did not yield results that differed strongly from those for the whole population of back trajectories.

As a last step in the discussion of seasonal variations in new particle formation, a model is formulated that describes the average sum of NPF events (TNPF) as a function of three parameters, two of which are directly measurable at the site. With the linear combination of the solar flux (SFL, $\mathrm{Wm}^{-2}$ ), average sea surface temperature under back trajectories 36 to $48 \mathrm{~h}$ before their arrival at the site $\left(T 48,{ }^{\circ} \mathrm{C}\right)$ and condensation sink $\left(\mathrm{CS}, 10^{5} \mathrm{~s}^{-1}\right)$ are

$\mathrm{TNPF}=0.57 \cdot \mathrm{SFL}+15.4 \cdot T 48-0.69 \cdot \mathrm{CS}$.

TNPF as shown in Fig. 10, can be described within an average deviation of $5 \%$ taken over the major months with new particle formation, April-October. Any other of the sea surface parameters describe TNPF less satisfactorily. 


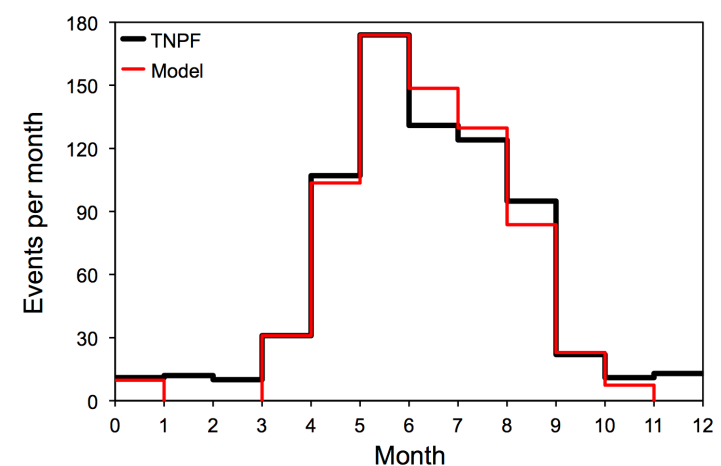

Figure 10. Average monthly sums of NPF events due to the three types of new particle formation (TNPF; black), summed up over the whole period of 10 years. Red: three-parameter model to describe TNPF.

\subsection{Diurnal variability}

Average hourly occurrence of the three types of NPF events is plotted in Fig. 11 (top). The three approaches yield rather similar diel variations. From their minimum during the night and early morning hours they reach their maximum occurrence between 12:00 and 16:00 UTC in the afternoon. One might expect the differences between the NPF types to be due to the requirement of the three types of NPF formation being mutually exclusive. However, this constraint does not exclude that they occur at the same time of day, only that they occur at the same time on the same day.

Over the continents new particle formation and growth events of the classical banana type usually exhibit an increase in measurable precursors, such as sulfuric acid, shortly after sunrise followed by the detection of increased numbers of nanometer-sized particles between 1 and $2 \mathrm{~h}$ later (Kulmala et al., 2004), which deduce a connection to photochemically produced condensable vapors from this daily pattern. In the Svalbard region the sun is up all day between midApril and the end of August. Consequently, we would expect the photochemical production of condensable vapors to have a smaller diurnal amplitude than at lower latitudes, which in turn should even out the diurnal pattern of NPF events to some degree. Despite the relatively small daily variations in solar elevations the solar flux on Mt. Zeppelin varied on average by more than a factor of 5 during the sunlit days (see curve SFL in Fig. 11, bottom). The daily maximum of SFL between 12:00 and 15:00 UTC coincides well with the average diel change in N25 and NPF occurrence. As expected in particle growth due to condensable vapors after initial nucleation, the daily maximum in $N 10$ precedes that of $N 25$ by a few hours.

The other process controlling the development of newly formed small particles is the diurnal development of the planetary boundary layer (Kulmala et al., 2004). We have no data on the daily variation in boundary layer structure over or near

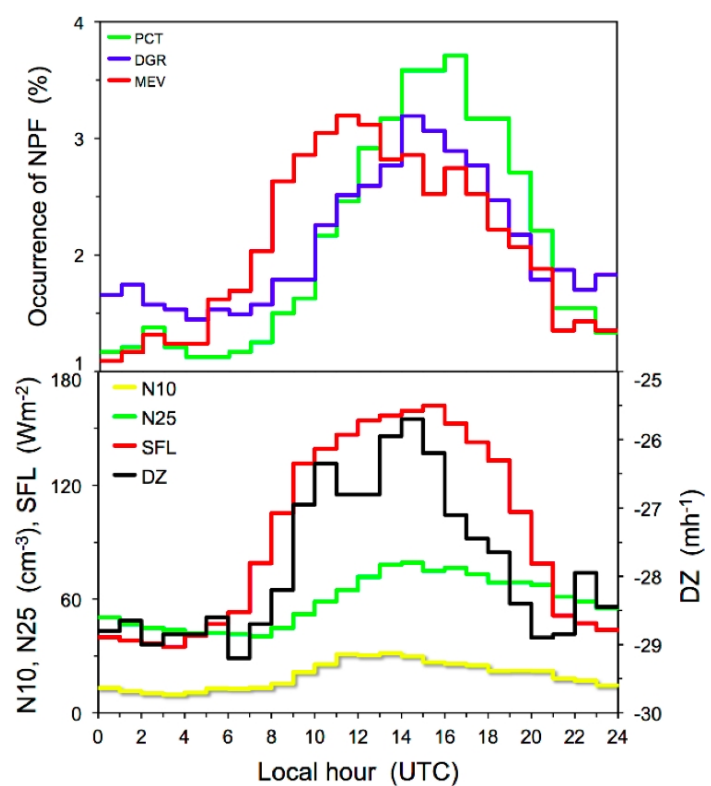

Figure 11. Top: relative average diurnal occurrence of the three types NPF events. PCT: upper percentile of N25; DGR: diameter growth; MEV: multiple-size events. Bottom: average diurnal variation of the HYSPLIT-modeled solar flux (SFL, $\mathrm{Wm}^{-2}$ ), the integral particle concentrations $N 10$ and $N 25$ in $\mathrm{cm}^{-3}$, and of the vertical displacement parameter (DZ, $\left.\mathrm{m} \mathrm{h}^{-1}\right) . N 10$ is based on data of the years 2011-2015, whereas the other parameters are based on data of the years 2006-2015.

the measurement site. The ceilometer data yield only highresolution information with some connection to the structure of the planetary boundary layer. During the summer months these data show a consistent daily variation with a jump in most frequent hourly cloud base by about $100 \mathrm{~m}$ from about $1570 \mathrm{~m}$ after 09:00 UTC with rather stable values following until 16:00 UTC, after which cloud base decreases again to values comparable to the early morning hours. The hourly medians of the vertical displacement parameter DZ,(see Fig. 11, bottom) provide a clearer diurnal variation. While being negative throughout the day, i.e., indicating subsiding air during the last hour before arrival at Mt. Zeppelin, DZ indicates the weakest subsidence in early afternoon. We interpret diurnal variation in cloud base and $\mathrm{DZ}$ as indicative of local clearing and convection during the day that may be conducive to photochemical processes and mixing in the boundary layer, both of which would be enhancing new particle formation.

\section{Summary and conclusions}

Three different types of events of new particle formation (NPF) were identified through objective search algorithms formulated for the present study. The first and simplest algorithm utilizes short-term increases in particle concentrations 
below $25 \mathrm{~nm}$ (PCT events). The second one builds on the growth of the sub-50 $\mathrm{nm}$ diameter median (DGR events), and is most closely related to the classical banana type of events (Kulmala et al., 2004) involving the presence of photochemically generated DMS oxidation precursors. The third and most complex, multiple-size approach to identifying NPF events builds on the hypothesis of Leck and Bigg (2010), suggesting the concurrent production of polymer gel particles at several sizes below about $60 \mathrm{~nm}$ (MEV events).

In this analysis the possibility that sporadic anthropogenic emissions, which were interpreted as NPF events, cannot be excluded completely. However, there are a number of facts arguing strongly against this possibility leading to serious misinterpretation of the data:

a. Location and operation of the Mt. Zeppelin station exclude local contamination to a very large extent.

b. Manual inspection of the time series by one of the coauthors (PT) further reduced the risk of contaminated data.

c. The temporal evolution of MEV events, i.e., concurrent and sustained concentration increases at several particle sizes below $60 \mathrm{~nm}$ does not correspond to a typical passage of stack emissions from a large combustion source (Ogren and Heintzenberg, 1990). Instead, it looks very much like MEV events observed under even stricter constraints on local or regional sources of contamination on icebreaker Oden in the central pack ice area (Karl et al., 2013), and also looks similar to nocturnal NPF events in Australian forests (Suni et al., 2008; Junninen et al., 2008).

With these algorithms NPF events were identified in a 10year record of hourly number-size distributions taken at the research station on Mt. Zeppelin, Spitsbergen. As a first and general conclusion we can state that NPF events are a summer phenomenon and not related to Arctic haze, which is a late winter to early spring event. The seasonal distribution of the available information on cloudiness does not suggest any direct connection with NPF formation. The MODISderived cloud fraction generally is very high $(70-90 \%)$ and rather evenly distributed over the Svalbard region during the months with high frequencies of NPF events. As already reported in Tunved et al. (2013), NPF events appear to be somewhat sensitive to the available data on precipitation derived from the trajectory model, in particular when constrained to cases with back trajectories staying below $500 \mathrm{~m}$. In this subpopulation of NPF events DGR events show the strongest change in precipitation parameters in connection with new particle formation.

The seasonal distribution of solar flux suggests some photochemical control that may affect marine biological processes generating particle precursors and/or atmospheric photochemical processes that generate condensable vapors from precursor gases. Whereas the seasonal distribution of the biogenic MSA follows that of the solar flux, it peaks before the maxima in NPF occurrence. For PCT events, and more distinctly so for DGR events, this 1-month delay disappears in the sub-population with back trajectories staying below $500 \mathrm{~m}$. MEV events, however, maintain their peak occurrence later in summer and early fall.

With the limited information on particle size, composition, particle precursors, and environmental conditions, no definitive statements can be made about the processes leading to the formation of new particles in the Svalbard region. A host of findings, however, point to varying and rather complex marine biological source processes. The potential source regions for all types of new particle formation appear to be restricted to the marginal-ice and open-water areas between northeastern Greenland and eastern Svalbard. During earliest and latest months with high numbers of NPF events, the back trajectories reach farther south into the open waters of the North Atlantic. Depending on conditions yet to be clarified, new particle formation may become visible as short bursts of particles around $20 \mathrm{~nm}$ (PCT events), longer events involving condensation growth (DGR events) or extended events with elevated concentrations of particles at several sizes below $100 \mathrm{~nm}$ (MEV events). The seasonal distribution of NPF events peaks later than that of MSA, and DGR, and in particular of MEV events, reach into late summer and early fall with much open, warm, and DMSPt-rich waters around Svalbard, promoting the production of Phaeocystis pouchetii together with polymer gels. Consequently, a simple model to describe the seasonal distribution of the total number of NPF events can be based on solar flux, and sea surface temperature, representing environmental conditions for marine biological activity, and condensation sink, controlling the balance between new particle nucleation and their condensational growth. Based on the sparse knowledge about the seasonal cycle of gel-forming marine microorganisms and their controlling factors, we hypothesize that the seasonal distribution of DGR and more so MEV events reflect the seasonal cycle of the gel-forming phytoplankton.

Despite the rather small diel changes expected during the summer Arctic, there is a significant diurnal variation in aerosol and environmental parameters. Diurnal distributions of particle numbers below $10(N 10)$ and below $25 \mathrm{~nm}(N 25)$ follow that of the solar flux rather closely with a maximum between 14:00 and 16:00 UTC with the maximum of $N 10$ occurring a few hours before that of $N 25$. This delay in maxima may be caused by a slow particle growth due to photochemically produced condensable vapors. With a peak around noon, MEV events show the earliest daily peak occurrence with PCT and DGR events peaking between 15 and $17 \mathrm{~h}$, more closely to the maximum solar flux. Considering the diurnal variation in vertical trajectory displacement (DZ), the early daily maximum in MEV occurrence may be simply controlled by boundary layer dynamics. 
With the large database of 10 years of aerosol data on Mt. Zeppelin enriched by environmental atmospheric and marine data occurrences, pathways and potential source areas of different types of new particle formation in the Svalbard region were elucidated by the present study. More processrelated information about new particle formation would require dedicated mechanistic experiments with more detailed information on particle precursors, ultrafine particles, and boundary layer mixing processes. DGR and MEV types of new particle formation seem to be more closely related to near-surface processes. Thus, a low-level site such as the reopened station Nord (Nguyen et al., 2016) would be more suitable for related mechanistic experiments. Station Nord has the additional advantage of being close to the potential source regions of DGR and MEV events identified by the present study.

Data availability. The primary aerosol data are available at http: //ebas.nilu.no (Tørseth et al., 2012). Complementing our own chemical analyses of Mt. Zeppelin filter data, sodium and sulfate results were taken from the EBAS database at the Norwegian Institute for Air Research (http://ebas.nilu.no), for which we are indebted to Anne-Gunn Hjellbrekke and Wenche Aas.

\section{The Supplement related to this article is available online at doi:10.5194/acp-17-6153-2017-supplement.}

Competing interests. The authors declare that they have no conflict of interest.

Acknowledgements. The back trajectories created through the local use of the HYSPLIT4 model developed, maintained, and generously distributed by the Air Resources Laboratory of NOAA were a backbone of the present study. We are very grateful for the ceilometer data provided by the Alfred Wegener Institute in Bremerhaven/Potsdam and to NSIDC for their providing daily Arctic sea ice data. We thank the NASA Ocean Biology Distributed Active Archive Center (OB.DAAC) for access to MODIS data sets. We are indebted to Yafang Cheng and Zhibin Wang for providing the algorithm for calculating the condensation sink. MG acknowledges the receipt of a Beatriu de Pinós post-doctoral fellowship funded by the Generalitat de Catalunya. Long-term funding of the DMPS measurements was provided by the Swedish Environmental Protection Agency (Naturvårdsverket). We also thank Norwegian Polar Institute for substantial support of the field operation on Mt. Zeppelin.

Edited by: J. Allan

Reviewed by: two anonymous referees

\section{References}

Agarwal, J. K. and Sem, G. J.: Continuous flow, single-particlecounting condensation nucleus counter, J. Aerosol Sci., 11, 343$357,1980$.

An, N. and Wang, K.: A Comparison of MODIS-Derived Cloud Fraction with Surface Observations at Five SURFRAD Sites, J. Appl. Meteor. Clim., 54, 1009-1020, 2015.

Asmi, E., Kondratyev, V., Brus, D., Laurila, T., Lihavainen, H., Backman, J., Vakkari, V., Aurela, M., Hatakka, J., Viisanen, Y., Uttal, T., Ivakhov, V., and Makshtas, A.: Aerosol size distribution seasonal characteristics measured in Tiksi, Russian Arctic, Atmos. Chem. Phys., 16, 1271-1287, doi:10.5194/acp-16-12712016, 2016.

Ayers, G. P., Cainey, J. M., Granek, H., and Leck, C.: Dimethylsulfide oxidation and the ratio of methansulfonate to non seasalt sulfate in the marine aerosol, J. Atmos. Chem., 25, 307-325, 1996.

Bates, T. S., Johnson, J. E., Quinn, P. K., Goldan, P. D., Kuster, W. C., Covert, D. C., and Hahn, C. J.: The biogeochemical sulfur cycle in the marine boundary layer over the Northeast Pacific Ocean, J. Atmos. Chem., 10, 59-81, 1990.

Becagli, S., Lazzara, L., Marchese, C., Dayan, U., Ascanius, S. E., Cacciani, M., Caiazzo, L., Di Biagio, C., Di Iorio, T., di Sarra, A., Eriksen, P., Fani, F., Giardi, F., Meloni, D., Muscari, G., Pace, G., Severi, M., Traversi, R., and Udisti, R.: Relationships linking primary production, sea ice melting, and biogenic aerosol in the Arctic, Atmos. Environ., 136, 1-15, doi:10.1016/j.atmosenv.2016.04.002, 2016.

Beine, H. J., Argentini, S., Maurizi, A., Mastrantonio, G., and Viola, A.: The local wind field at Ny-Ålesund and the Zeppelin mountain at Svalbard, Meteorol. Atmos. Phys., 78, 107-113, 2001.

Bélanger, S., Babin, M., and Tremblay, J.-É.: Increasing cloudiness in Arctic damps the increase in phytoplankton primary production due to sea ice receding, Biogeosciences, 10, 4087-4101, doi:10.5194/bg-10-4087-2013, 2013.

Blanchard, D. C. and Woodcock, A. H.: Bubble formation and modification in the sea and its meteorological significance, Tellus, 9, 145-158, 1957.

Browse, J., Carslaw, K. S., Mann, G. W., Birch, C. E., Arnold, S. R., and Leck, C.: The complex response of Arctic aerosol to sea-ice retreat, Atmos. Chem. Phys., 14, 7543-7557, doi:10.5194/acp14-7543-2014, 2014.

Charlson, R. J., Lovelock, J. E., Andreae, M. O., and Warren, S. G.: Oceanic phytoplankton, atmospheric sulphur, cloud albedo and climate, Nature, 326, 655-661, 1987.

Croft, B., Martin, R. V., Leaitch, W. R., Tunved, P., Breider, T. J., D'Andrea, S. D., and Pierce, J. R.: Processes controlling the annual cycle of Arctic aerosol number and size distributions, Atmos. Chem. Phys., 16, 3665-3682, doi:10.5194/acp-16-36652016, 2016 a.

Croft, B., Wentworth, G. R., Martin, R. V., Leaitch, W. R., Murphy, J. G., Murphy, B. N., Kodros, J. K., Abbatt, J. P. D., and Pierce, J. R.: Contribution of Arctic seabird-colony ammonia to atmospheric particles and cloud-albedo radiative effect, Nature Communications, 7, 13444, doi:10.1038/ncomms13444, $2016 \mathrm{~b}$.

Dal Maso, M., Kulmala, M., Riipinen, I., Wagner, R., Hussein, T., Aalto, P. P., and Lehtinen, K. E. J.: Formation and growth of fresh atmospheric aerosols: eight years of aerosol size distribution data 
from SMEAR II, Hyytiälä, Finland, Bor. Env. Res., 10, 323-336, 2005.

Das, R., Granat, L., Leck, C., Praveen, P. S., and Rodhe, H.: Chemical composition of rainwater at Maldives Climate Observatory at Hanimaadhoo (MCOH), Atmos. Chem. Phys., 11, 3743-3755, doi:10.5194/acp-11-3743-2011, 2011.

Dee, D. P., Uppala, S. M., Simmons, A. J., Berrisford, P., Poli, P., Kobayashi, S., and Bechtold, P.: The ERA Interim reanalysis: Configuration and performance of the data assimilation system, Q. J. Roy. Meteor. Soc., 137, 553-597, 2011.

Draxler, R. and Rolph, G.: HYSPLIT (HYbrid Single-Particle Lagrangian Integrated Trajectory) Model access via NOAA ARL READY, NOAA Air Resources Laboratory, Silver Spring, MD, 2003.

Ehn, M., Vuollekoski, H., Petäjä, T., Kerminen, V.-M., Vana, M., Aalto, P., de Leeuw, G., Ceburnis, D., Dupuy, R., O'Dowd, C. D., and Kulmala, M.: Growth rates during coastal and marine new particle formation in western Ireland, J. Geophys. Res., 115, 2156-2202, doi:10.1029/2010JD014292, 2010.

Flyger, H. and Heidam, N. Z.: Ground level measurements of the summer tropospheric aerosol in Northern Greenland, J. Aerosol Sci., 9, 157-168, 1978.

Galí, M. and Simó, R.: A meta analysis of oceanic DMS and DMSP cycling processes: Disentangling the summer paradox, Global Biogeochem. Cy., 29, 496-515, 2015.

Galí, M., Devred, E., Levasseur, M., Royer, S.-J., and Babin, M.: A remote sensing algorithm for planktonic dimethylsulfoniopropionate (DMSP) and an analysis of global patterns, Remote Sens. Environ., 171, 171-184, doi:10.1016/j.rse.2015.10.012, 2015.

Gao, Q., Leck, C., Rauschenberg, C., and Matrai, P. A.: On the chemical dynamics of extracellular polysaccharides in the high Arctic surface microlayer, Ocean Sci., 8, 401-418, doi:10.5194/os-8-401-2012, 2012.

Heintzenberg, J.: Arctic haze: air pollution in polar regions, AMBIO, 18, 50-55, 1989.

Heintzenberg, J.: The aerosol-cloud-climate conundrum, IJGW, 4, 219-241, 2012.

Heintzenberg, J. and Larssen, S.: $\mathrm{SO}_{2}$ and $\mathrm{SO}_{4}$ in the Arctic: Interpretation of observations at three Norwegian Arctic-subArctic stations, Tellus, 35B, 255-265, 1983.

Heintzenberg, J. and Leck, C.: Seasonal variation of the atmospheric aerosol near the top of the marine boundary layer over Spitsbergen related to the Arctic sulphur cycle, Tellus, 46B, 5267, 1994.

Heintzenberg, J., Bischof, W., Odh, S.-Å., and Moberg, B.: An investigation of possible sites for a background monitoring station in the European Arctic, International Meteorological Institute in Stockholm, Department of Meteorology, Stockholm University, Stockholm, Report Nr. AP-22, 74 pp., 1983.

Heintzenberg, J., Leck, C., Birmili, W., Wehner, B., Tjernström, M., and Wiedensohler, A.: Aerosol number-size distributions during clear and fog periods in the summer high Arctic: 1991, 1996, and 2001, Tellus, 58B, 41-50, 2006.

Heintzenberg, J., Wehner, B., and Birmili, W.: "How to find bananas in the atmospheric aerosol" New approach for analyzing atmospheric nucleation and growth events, Tellus B, 59, 273282, 2007.
Heintzenberg, J., Leck, C., and Tunved, P.: Potential source regions and processes of aerosol in the summer Arctic, Atmos. Chem. Phys., 15, 6487-6502, doi:10.5194/acp-15-6487-2015, 2015.

Held, A., Brooks, I. M., Leck, C., and Tjernström, M.: On the potential contribution of open lead particle emissions to the central Arctic aerosol concentration, Atmos. Chem. Phys., 11, 30933105, doi:10.5194/acp-11-3093-2011, 2011a.

Held, A., Orsini, D. A., Vaattovaara, P., Tjernström, M., and Leck, C.: Near-surface profiles of aerosol number concentration and temperature over the Arctic Ocean, Atmos. Meas. Tech., 4, 1603-1616, doi:10.5194/amt-4-1603-2011, 2011 b.

Hubanks, P., Platnick, S., King, M., and Ridgway, B.: MODIS Atmosphere L3 Gridded Product Algorithm Theoretical Basis, Document (ATBD) and Users Guide, 2015.

Huschke, R. E.: Arctic cloud statistics from "air calibrated" surface weather observations, Rand Corporation Memo. RM 6173-PR, 79 pp., 1969.

IOCCG: Ocean Colour Remote Sensing, in: Polar Seas, Report 16, edited by: Babin, M., Arrigo, K., Bélanger, S., and Forget, M.-H., 129 pp., 2015.

Jaenicke, R. and Schütz, L.: Arctic aerosols in surface air, Idöjaras, 86, 235-241, 1982.

Junge, C. E.: Air chemistry and Radioactivity, Academic Press, New York and London, 382 pp., 1963.

Junninen, H., Hulkkonen, M., Riipinen, I., Nieminen, T., Hirsikko, A., Suni, T., Boy, M., Lee, S.-H., Vana, M., Tammet, H., Kerminen, V.-M., and Kulmala, M.: Observations on nocturnal growth of atmospheric clusters, Tellus B, 60, 365-371, 2008.

Karl, M., Gross, A., Leck, C., and Pirjola, L.: Intercomparison of dimethylsulfide oxidation mechanisms for the marine boundary layer: Gaseous and particulate sulfur constituents, J. Geophys. Res., 112, D15304, doi:10.1029/2006JD007914, 2007.

Karl, M., Leck, C., Gross, A., and Pirjola, L.: A Study of New Particle Formation in the Marine Boundary Layer Over the Central Arctic Ocean using a Flexible Multicomponent Aerosol Dynamic Model, Tellus B, 64, 17158, doi:10.3402/tellusb.v64i0.17158, 2012.

Karl, M., Leck, C., Coz, E., and Heintzenberg, J.: Marine nanogels as a source of atmospheric nanoparticles in the high Arctic, Geophys. Res. Lett., 40, 3738-3743, doi:10.1002/grl.50661, 2013.

Keene, W. C., Pszenny, A. A. P., Galloway, J. N., and Hawley, M. E.: Sea-salt corrections and interpretation of constituent ratios in marine precipitation, J. Geophys. Res., 91, 6647-6658, 1986.

Keller, M. D., Bellows, W. K., and Guillard, R. R. L.: A survey of dimethylsulfide production in 12 classes of marine phytoplankton, in: Biogenic sulfur in the environment, edited by: Saltzman, E. S. and Cooper, W. J., American Chemical Society, Washington, 167-182, 1989.

King, M. D., Platnick, S., Menzel, W. P., Ackerman, S. A., and Hubanks, P. A.: Spatial and temporal distribution of clouds observed by MODIS onboard the Terra and Aqua satellites, IEEE Trans. Geosci. Remote Sens., 51, 3826-3852, 2013.

Knutson, E. O. and Whitby, K. T.: Aerosol classification by electric mobility: apparatus, theory, and applications, J. Aerosol Sci., 6, 443-451, 1975a.

Knutson, E. O. and Whitby, K. T.: Accurate Measurement of Aerosol Electrical Mobility Moments, J. Aerosol Sci., 6, 453460, 1975 b. 
Kulmala, M., Dal Maso, M., Mäkelä, J. M., Pirjola, L., Väkevä, M., Aalto, P. P., Miikkulainen, P., Hämeri, K., and O’Dowd, C. D.: On the formation, growth and composition of nucleation mode particles, Tellus, 53B, 479-490, 2001.

Kulmala, M., Vehkamäkia, H., Petäjä, T., Dal Maso, M., Lauri, A., Kerminen, V.-M., Birmili, W., and McMurry, P. H.: Formation and growth rates of ultrafine atmospheric particles: a review of observations, J. Aerosol Sci., 35, 143-176, 2004.

Kulmala, M., Petäjä, T., Nieminen, T., Sipilä, M., Manninen, H. E., Lehtipalo, K., Dal Maso, M., Aalto, P. P., Junninen, H., Paasonen, P., Riipinen, I., Lehtinen, K. E. J., Laaksonen, A., and Kerminen, V.-M.: Measurement of the nucleation of atmospheric aerosol particles, Nat. Protocols, 7, 1651-1667, 2012.

Lana, A., Simó, R., Vallina, S. M., and Dachs, J.: Re-examination of global emerging patterns of ocean DMS concentration, Biogeochem., 110, 173-182, 2012.

Lannefors, H., Heintzenberg, J., and Hansson, H.-C.: A comprehensive study of physical and chemical parameters of the Arctic summer aerosol; results from the Swedish expedition Ymer-80, Tellus, 35B, 40-54, 1983.

Leck, C. and Bigg, E. K.: New particle formation of marine biological origin, Aerosol Sci. Technol., 44, 570-577, 2010.

Leck, C. and Persson, C.: The central Arctic Ocean as a source of dimethyl sulfide: Seasonal variability in relation to biological activity, Tellus, 48B, 156-177, 1996a.

Leck, C. and Persson, C.: Seasonal and short-term variability in dimethyl sulfide, sulfur dioxide and biogenic sulfur and sea salt aerosol particles in the arctic marine boundary layer, during summer and autumn, Tellus, 48B, 272-299, 1996b.

Leck, C. and Bigg, E. K.: Aerosol production over remote marine areas - A new route, Geophys. Res. Lett., 23, 3577-3581, 1999.

Leck, C., Gao, Q., Mashayekhy Rad, F., and Nilsson, U.: Size-resolved atmospheric particulate polysaccharides in the high summer Arctic, Atmos. Chem. Phys., 13, 12573-12588, doi:10.5194/acp-13-12573-2013, 2013.

Lindsay, R., Wensnahan, M., Schweiger, A., and Zhang, J.: Evaluation of seven different atmospheric reanalysis products in the Arctic, J. Climate, 27, 2588-2606, 2014.

Liss, P. S. and Merlivat, L.: Air-sea gas exchange rates: Introduction and synthesis, in: The Role of Air-Sea Exchange in Geochemical Cycling, edited by: Buat-Menard, P., D. Reidel Publishing Company, Norwell, M.S., 113-127, 1986.

Maritorena, S., Siegel, D. A., and Peterson, A. R.: Optimization of a semianalytical ocean color model for global-scale applications, Appl. Opt., 41, 2705-2714, 2002.

Matrai, P. A. and Vernet, M.: Dynamics of the vernal bloom in the marginal ice zone of the Barents Sea: Dimethyl sulfide and dimethylsulfoniopropionate budgets, J. Geophys. Res.-Oceans, 102, 22965-22979, doi:10.1029/96JC03870, 1997.

Nguyen, Q. T., Glasius, M., Sørensen, L. L., Jensen, B., Skov, H., Birmili, W., Wiedensohler, A., Kristensson, A., Nøjgaard, J. K., and Massling, A.: Seasonal variation of atmospheric particle number concentrations, new particle formation and atmospheric oxidation capacity at the high Arctic site Villum Research Station, Station Nord, Atmos. Chem. Phys., 16, 11319-11336, doi:10.5194/acp-16-11319-2016, 2016.

Norman, A. L., Barrie, L. A., Toom-Sauntry, D., Sirois, A., Krouse, H. R., Li, S. M., and Sharma, S.: Sources of aerosol sulphate at Alert: Apportionment using stable isotopes, J. Geophys. Res., 104, 11619-11631, 1999.

O’Dowd, C., Monahan, C., and Dall'Osto, M.: On the occurrence of open ocean particle production and growth events, Geophys. Res. Lett., 37, L19805, doi:10.1029/2010GL044679, 2010.

Ogren, J. A. and Heintzenberg, J.: Parametric aerosol sampling at low concentration levels, Department of Meteorology, Stockholm UniversityAA-1, 1990.

Orellana, M. V., Matrai, P. A., Janer, M., and Rauschenberg, C. D.: Dimethylsulfoniopropionate storage in Phaecystis (Prymnesiophyceae) secretory vesicles J. Phycol., 47, 112-117, doi:10.1111/j.1529-8817.2010.00936.x, 2011a.

Orellana, M. V., Matrai, P. A., Leck, C., Rauschenberg, C. D., Lee, A. M., and Coz, E.: Marine microgels as a source of cloud condensation nuclei in the high Arctic, PNAS, 108, 13612-13617, 2011b.

Pierce, J. R., Westervelt, D. M., Atwood, S. A., Barnes, E. A., and Leaitch, W. R.: New-particle formation, growth and climaterelevant particle production in Egbert, Canada: analysis from 1 year of size-distribution observations, Atmos. Chem. Phys., 14, 8647-8663, doi:10.5194/acp-14-8647-2014, 2014.

Pirjola, L., Kulmala, M., Wilck, M., Bischoff, A., Stratmann, F., and Otto, E.: Formation of sulphuric acid aerosols and cloud condensation nuclei: An expression for significant nucleation and model comparison, J. Aerosol Sci., 30, 1079-1094, 1999.

Polissar, A. V., Hopke, P. K., Paatero, P., Kaufman, Y. J., Hall, D. K., Bodhaine, B. A., Dutton, E. G., and Harris, J. M.: The aerosol at Barrow, Alaska: long-term trends and source locations, Atmos. Environ., 33, 2441-2458, 1999.

Rahn, K. A. and Shaw, G. E.: Particulate air pollution in the Arctic: Large-scale occurence and meteorological controls, in: Atmospheric Aerosols and Nuclei, edited by: Roddy, F. and O'Connor, T. C., Dept. of Physics, University College, Galway, Ireland 2127 September, 223-227, 1977.

Reischl, G. P.: Measurement of ambient aerosols by the differential mobility analyzer method: Concepts and realization criteria for the size range between 2 and $500 \mathrm{~nm}$, Aerosol Sci. Tech., 14, 524, 1991.

Ristovski, Z. D., Suni, T., Kulmala, M., Boy, M., Meyer, N. K., Duplissy, J., Turnipseed, A., Morawska, L., and Baltensperger, U.: The role of sulphates and organic vapours in growth of newly formed particles in a eucalypt forest, Atmos. Chem. Phys., 10, 2919-2926, doi:10.5194/acp-10-2919-2010, 2010.

Rudels, B., Björk, G., Nilsson, J., Winsor, P., Lake, I., and Nohr, C.: The interaction between waters from the Arctic Ocean and the Nordic Seas north of Fram Strait and along the East Greenland Current: results from the Arctic Ocean-02 Oden expedition, J. Marine Syst., 55, 1-30, 2005.

Schmidtko, S., Johnson, G. C., and Lyman, J. M.: MIMOC: A global monthly isopycnal upper-ocean climatology with mixed layers, J. Geophys. Res.-Oceans, 118, 1658-1672, doi:10.1002/jgrc.20122, 2013.

Schoemann, V., Becquevort, S., Stefels, J., Rousseau, V., and Lancelot, C.: Phaeocystis blooms in the global ocean and their controlling mechanisms: a review, J. Sea Res., 53, 43-66, doi:10.1016/j.seares.2004.01.008, 2005.

Sharma, S., Chan, E., Ishizawa, M., Toom-Sauntry, D., Gong, S. L., Li, S. M., Tarasick, D. W., Leaitch, W. R., Norman, A., Quinn, P. K., Bates, T. S., Levasseur, M., Barrie, L. A., and Maenhaut, W.: 
Influence of transport and ocean ice extent on biogenic aerosol sulfur in the Arctic atmosphere, J. Geophys. Res., 117, D12209, doi:10.1029/2011JD017074, 2012.

Simó, R.: Production of atmospheric sulfur by oceanic plankton: biogeochemical, ecological and evolutionary links, Trends Ecol. Evol., 16, 287-294, 2001.

Stohl, A.: Computations, accuracy and applications of trajectories A review and bibliography, Atmos. Environ., 32, 947-966, 1998.

Ström, J., Engvall, A.-C., Delbart, F., Krejci, R., and Treffeisen, R.: On small particles in the Arctic summer boundary layer: observations at two different heights near Ny-Ålesund, Svalbard, Tellus B, 61, 473-482, 2009.

Suni, T., Kulmala, M., Hirsikko, A., Bergman, T., Laakso, L., Aalto, P. P., Leuning, R., Cleugh, H., Zegelin, S., Hughes, D., van Gorsel, E., Kitchen, M., Vana, M., Hõrrak, U., Mirme, S., Mirme, A., Sevanto, S., Twining, J., and Tadros, C.: Formation and characteristics of ions and charged aerosol particles in a native Australian Eucalypt forest, Atmos. Chem. Phys., 8, 129-139, doi:10.5194/acp-8-129-2008, 2008.

Tørseth, K., Aas, W., Breivik, K., Fjæraa, A. M., Fiebig, M., Hjellbrekke, A. G., Lund Myhre, C., Solberg, S., and Yttri, K. E.: Introduction to the European Monitoring and Evaluation Programme (EMEP) and observed atmospheric composition change during 1972-2009, Atmos. Chem. Phys., 12, 54475481, doi:10.5194/acp-12-5447-2012, 2012 (data available at: http://ebas.nilu.no).

Tunved, P., Ström, J., and Krejci, R.: Arctic aerosol life cycle: linking aerosol size distributions observed between 2000 and 2010 with air mass transport and precipitation at Zeppelin station, Ny-Ålesund, Svalbard, Atmos. Chem. Phys., 13, 3643-3660, doi:10.5194/acp-13-3643-2013, 2013.
Venzac, H., Sellegri, K., Villani, P., Picard, D., and Laj, P.: Seasonal variation of aerosol size distributions in the free troposphere and residual layer at the puy de Dôme station, France, Atmos. Chem. Phys., 9, 1465-1478, doi:10.5194/acp-9-1465-2009, 2009.

Warren, S. G., and Hahn, C. J.: Cloud climatology, in: Encyclopedia of Atmospheric Sciences, edited by: Holton, J. R., Pyle, J., and Curry, J. A., Academic Press, London, UK, 476-483, 2002.

Wiedensohler, A., Covert, D., Swietlicki, E., Aalto, P., Heintzenberg, J., and Leck, C.: Occurrence of an ultrafine particle mode less than $20 \mathrm{~nm}$ in diameter in the marine boundary layer of the Arctic summer and autumn, Tellus, 48B, 213-222, 1996.

Willis, M. D., Burkart, J., Thomas, J. L., Köllner, F., Schneider, J., Bozem, H., Hoor, P. M., Aliabadi, A. A., Schulz, H., Herber, A. B., Leaitch, W. R., and Abbatt, J. P. D.: Growth of nucleation mode particles in the summertime Arctic: a case study, Atmos. Chem. Phys., 16, 7663-7679, doi:10.5194/acp-16-76632016, 2016.

Yli-Juuti, T., Riipinen, I., Pasi, A., Nieminen, T., Maenhaut, W., Janssens, A., Claeys, M., Salma, I., Ocskay, R., Hoffer, A., Imre, K., and Kulmala, M.: Characteristics of new particle formation events and cluster ions at K-puszta, Hungary, Boreal Environ. Res., 14, 683-698, 2009.

Young, L.-H., Lee, S.-H., Kanawade, V. P., Hsiao, T.-C., Lee, Y. L., Hwang, B.-F., Liou, Y.-J., Hsu, H.-T., and Tsai, P.-J.: New particle growth and shrinkage observed in subtropical environments, Atmos. Chem. Phys., 13, 547-564, doi:10.5194/acp-13547-2013, 2013.

Zhang, M., Chen, L., Xu, G., Lin, Q., and Liang, M.: Linking Phytoplankton Activity in Polynyas and Sulfur Aerosols over Zhongshan Station, East Antarctica, J. Atmos. Sci., 72, 4629-4642, 2015. 